\title{
Evaluation of the Benefits Attributable to Automotive Lightweight Materials Program Research and Development Projects
}

November 2001

Prepared by

Sujit Das

Oak Ridge National Laboratory

Jean H. Peretz

The University of Tennessee

Bruce Tonn

Oak Ridge National Laboratory 


\title{
DOCUMENT AVAILABILITY
}

Reports produced after January 1, 1996, are generally available free via the U.S. Department of Energy (DOE) Information Bridge:

Web site: http://www.osti.gov/bridge

Reports produced before January 1, 1996, may be purchased by members of the public from the following source:

\author{
National Technical Information Service \\ 5285 Port Royal Road \\ Springfield, VA 22161 \\ Telephone: 703-605-6000 (1-800-553-6847) \\ TDD: 703-487-4639 \\ Fax: 703-605-6900 \\ E-mail: info@ntis.fedworld.gov \\ Web site: http://www.ntis.gov/support/ordernowabout.htm
}

Reports are available to DOE employees, DOE contractors, Energy Technology Data Exchange (ETDE) representatives, and International Nuclear Information System (INIS) representatives from the following source:

Office of Scientific and Technical Information

P.O. Box 62

Oak Ridge, TN 37831

Telephone: 865-576-8401

Fax: 865-576-5728

E-mail: reports@adonis.osti.gov

Web site: http://www.osti.gov/contact.html

This report was prepared as an account of work sponsored by an agency of the United States Government. Neither the United States government nor any agency thereof, nor any of their employees, makes any warranty, express or implied, or assumes any legal liability or responsibility for the accuracy, completeness, or usefulness of any information, apparatus, product, or process disclosed, or represents that its use would not infringe privately owned rights. Reference herein to any specific commercial product, process, or service by trade name, trademark, manufacturer, or otherwise, does not necessarily constitute or imply its endorsement, recommendation, or favoring by the United States Government or any agency thereof. The views and opinions of authors expressed herein do not necessarily state or reflect those of the United States Government or any agency thereof. 


\title{
EVALUATION OF THE BENEFITS ATTRIBUTABLE TO Automotive Lightweight Materials Program RESEARCH AND DEVELOPMENT PROJECTS
}

\author{
November 2001 \\ Sujit Das \\ Engineering Science and Technology Division \\ Oak Ridge National Laboratory \\ Jean H. Peretz \\ Energy, Environment and Resources Center \\ The University of Tennessee \\ Bruce E. Tonn \\ Environmental Sciences Division \\ Oak Ridge National Laboratory \\ Prepared for \\ Automotive Lightweight Materials Program \\ Office of Advanced Automotive Technologies \\ of the \\ U.S. DEPARTMENT OF ENERGY \\ Prepared by the \\ OAK RIDGE NATIONAL LABORATORY \\ Oak Ridge, Tennessee 37831-6206 \\ Managed by \\ UT-BATTELLE \\ for the \\ U.S. DEPARTMENT OF ENERGY \\ under contract DE-AC05-00OR22725
}





\section{CONTENTS}

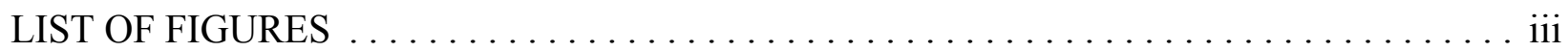

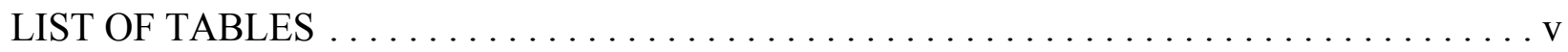

EXECUTIVE SUMMARY $\ldots \ldots \ldots \ldots \ldots \ldots \ldots \ldots \ldots \ldots \ldots \ldots \ldots \ldots \ldots \ldots \ldots$ vii

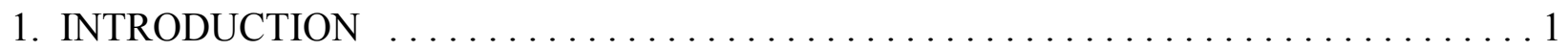

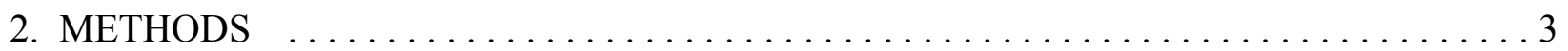

2.1 REVIEW OF COMMONLY USED BENEFIT ESTIMATION METHODS . . . . 3

2.2 METHODS USED FOR BENEFIT ESTIMATION $\ldots \ldots \ldots \ldots \ldots \ldots \ldots . . \ldots$

2.2.1 Qualitative Assessment ........................... 8

2.2.2 National Research Council Indicators $\ldots \ldots \ldots \ldots \ldots \ldots \ldots$

2.2.3 Benefit-Cost Analysis ............................ 9

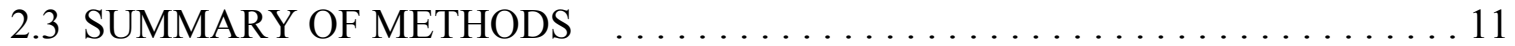

3. AUTOMOTIVE LIGHTWEIGHT MATERIALS PROJECTS $\ldots \ldots \ldots \ldots \ldots \ldots \ldots$

3.1 LOW-COST, CONTINUOUS CAST ALUMINUM SHEET $\ldots \ldots \ldots \ldots \ldots 13$

3.2 ADVANCED FORMING TECHNOLOGIES FOR ALUMINUM . ......... 14

3.3 MANUFACTURING OF COMPOSITE AUTOMOTIVE STRUCTURES $\ldots \ldots 15$

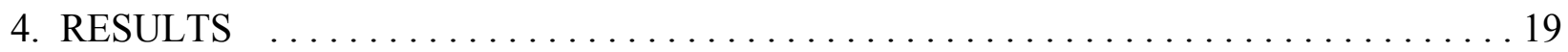

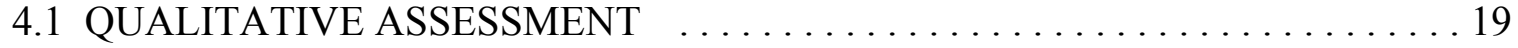

4.1 .1 Interviews ....................................... 19

4.1.2 Low-cost, Continuous Cast Aluminum Sheet Project $\ldots \ldots \ldots \ldots \ldots 20$

4.1.3 Advanced Forming Technologies for Aluminum Project ........... 21

4.1.4 Manufacturing of Composite Automotive Structures Project ........22

4.1.5 Qualitative Assessment Summary ..................... 24

4.2 NATIONAL RESEARCH COUNCIL INDICATORS $\ldots \ldots \ldots \ldots \ldots \ldots \ldots 25$

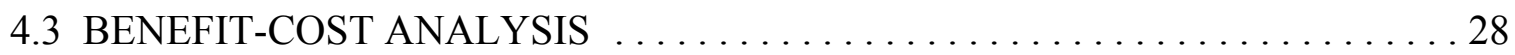

4.3.1 Market Penetration .............................. 28

4.3.2 Market Forecasts ............................ 28

4.3.3 Energy, Environmental, and Production Efficiency Benefits . . . . . . 35

4.3.4 Market Penetration Benefit Estimates $\ldots \ldots \ldots \ldots \ldots \ldots \ldots \ldots$

4.3.5 Benefit-Cost Ratios ............................... 39

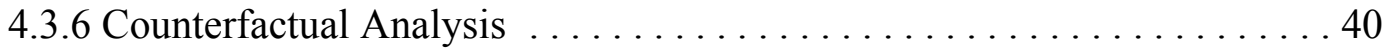

4.3.7 Benefit-Cost Approach Summary ....................... 41

4.4 TRACKING FUTURE BENEFITS $\ldots \ldots \ldots \ldots \ldots \ldots \ldots \ldots \ldots \ldots \ldots \ldots \ldots \ldots \ldots \ldots \ldots$

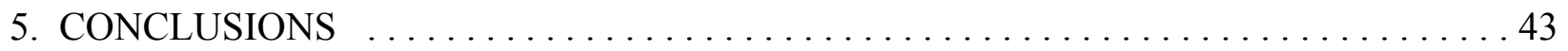

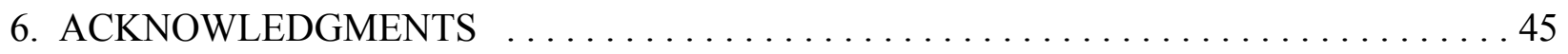

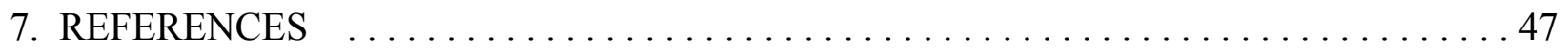





\section{LIST OF FIGURES}

Figure 4.1. Forecast of Effects of Low Cost 5000-series Aluminum Sheet . . . . . . . . . 30

Figure 4.2. Low Cost Aluminum Sheet and Advanced Forming Forecast $\ldots \ldots \ldots 31$

Figure 4.3. Forecast of Effects of New Automotive Aluminum Forming Technologies . . . 32

Figure 4.4. Manufacturing of Automotive Composite Structures Forecast . . . . . . . . . 34

Figure 4.5. Alternative Forecasts of Automotive Composite Structures . . . . . . . . 35 



\section{LIST OF TABLES}

Table E.S.1. Summary of qualitative assessments $\ldots \ldots \ldots \ldots \ldots \ldots \ldots \ldots \ldots$ viii

Table E.S.2. National Research Council indicators $\ldots \ldots \ldots \ldots \ldots \ldots \ldots \ldots \ldots$ ix

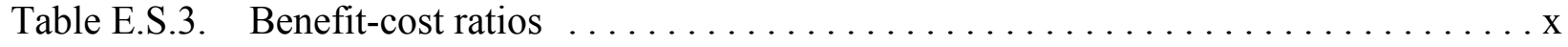

Table 2.1. Evaluation methods commonly used $\ldots \ldots \ldots \ldots \ldots \ldots \ldots \ldots \ldots$

Table 2.2. Benefits evaluation methods used in this research $\ldots \ldots \ldots \ldots \ldots \ldots \ldots$

Table 3.1. Projects that contributed to manufacturing of automotive composite structures . 17

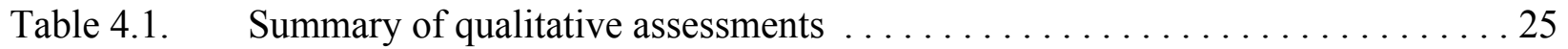

Table 4.2. National Research Council indicators $\ldots \ldots \ldots \ldots \ldots \ldots \ldots \ldots \ldots \ldots$

Table 4.3. Energy and environmental savings per pound of material used $\ldots \ldots \ldots 36$

Table 4.4. Energy and environmental emission values scenarios . . . . . . . . . 37

Table 4.5. Energy and environmental benefit results $(\$$ millions $) \ldots \ldots \ldots \ldots$

Table 4.6. Cost reductions associated with continuous casting of aluminum:

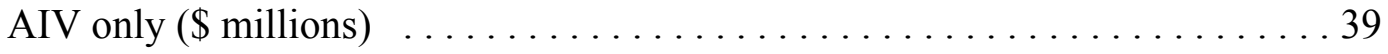

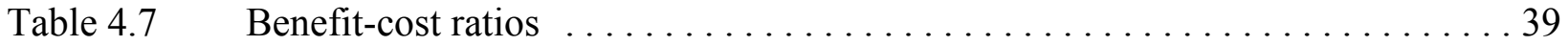

Table 4.8. Counterfactual benefit estimates $\ldots \ldots \ldots \ldots \ldots \ldots \ldots \ldots \ldots \ldots \ldots \ldots \ldots \ldots$ 



\section{EXECUTIVE SUMMARY}

The purpose of this project is to identify and test methods appropriate for estimating the benefits attributable to research and development (R\&D) projects funded by the Automotive Lightweight Materials (ALM) Program of the Office of Advanced Automotive Technologies (OAAT) of the U.S. Department of Energy (DOE). Funded projects range from basic materials science research to applied research in production environments. Collaborators on these projects include national laboratories, universities, and private sector firms, such as leading automobile manufacturers and their suppliers.

Three ALM R\&D projects were chosen for this pilot evaluation: Low-Cost, Continuous Cast Aluminum Sheet; Advanced Forming Technologies for Aluminum; and Manufacturing of Composite Automotive Structures. These projects were chosen because they represent a range of benefits evaluation situations. The first project resulted in an improved process that may be commercialized. The second project is on going and has two distinct components. The third project has yielded an improved technology that has been commercialized. This completed project also benefited from numerous complementary projects.

Through a thorough literature review, researchers identified methods to estimate benefits attributable to $R \& D$ projects and reviewed applications of the methods. This review led to three approaches to assessing the benefits attributable to ALM projects:

- Qualitative Assessment. Participant views about the benefits of the projects were assessed through interviews. Questions addressed whether: the projects' technical objectives were met; the projects yielded new knowledge; the projects would have been conducted without federal support; and the projects enhanced collaboration among the participants.

- National Research Council Indicators. Through interviews and project materials, the number of publications associated with the projects were enumerated. Researchers established whether the projects benefited from outside peer review and determined whether the projects enhanced U.S. international competitiveness.

- Benefit-Cost Analysis. Monetized values for the benefits and costs of the project were estimated. The benefits are mainly due to the accelerated commercialization of new technologies but are also associated with benefits received to companies from the federal support. Forecasts of market penetration of new vehicles benefiting from the new technologies were developed with and without federal support out to the year 2025. Benefits examined include energy savings, reductions in air pollutants (e.g., carbon dioxide $\left(\mathrm{CO}_{2}\right)$, nitrogen oxides (NOx)), and production cost savings. Values were assigned to each benefit, and benefits and costs were estimated out to the year 2025. Costs were defined as DOE support and private sector cost sharing. Net present values for the benefits were calculated. The ratio of project benefits defined to encompass benefits attributable to the accelerated commercialization of the technologies, to costs was also calculated for each project. We also examined the savings in person-years gained by industry having access to federal R\&D funding; we did not include these person-year savings in the benefit-cost ratio. 
In combination, these approaches address all-important aspects of the benefits of R\&D projects. All three approaches address short-term benefits. Long-term benefits are mainly addressed by the benefit-cost analysis, although future evaluation can be conducted to track additional publications and their citation in the literature, spin-off technologies, and actual market penetration rates.

Table E.S.1. presents the results of the qualitative assessment. Overall, the qualitative assessment is very positive for the three projects. All the technical objectives were met and all yielded new knowledge. In one case, all private sector participants interviewed indicated that they would not have participated in the R\&D without federal funding. In the second and third R\&D projects, one participant interviewed from each project indicated his company would have proceeded but with considerably less funding, breadth of research, and speed as achieved with DOE funding. With regard to the other interviewees from the forming and composite projects, they noted that the financial resources would not have been available within an individual firm for this large scale research effort. Collaboration among the participants was enhanced. The only major uncertainty relates to commercialization. One technology, related to composites, has been commercialized. Time is needed in the other areas to ascertain whether the technologies will be commercialized.

Table E.S.1. Summary of qualitative assessments

\begin{tabular}{|c|c|c|c|c|c|}
\hline Project & $\begin{array}{c}\text { Met } \\
\text { technical } \\
\text { objectives? }\end{array}$ & $\begin{array}{l}\text { Yielded new } \\
\text { knowledge? }\end{array}$ & $\begin{array}{l}\text { Will technology } \\
\text { be } \\
\text { commercialized? }\end{array}$ & $\begin{array}{c}\text { Would company } \\
\text { have participated } \\
\text { without federal } \\
\text { funding? }\end{array}$ & $\begin{array}{c}\text { Was } \\
\text { collaboration } \\
\text { enhanced? }\end{array}$ \\
\hline $\begin{array}{l}\text { Continuous } \\
\text { cast }\end{array}$ & Yes & Yes & Mixed opinion & No & Yes \\
\hline $\begin{array}{l}\text { Aluminum } \\
\text { forming }\end{array}$ & Yes & Yes & Uncertain & $\begin{array}{l}\text { Mixed opinion. For } \\
\text { those who would have, } \\
\text { not with as many } \\
\text { resources or at speed } \\
\text { of commercialization. }\end{array}$ & Yes \\
\hline Composites & Yes & Yes & Yes & $\begin{array}{l}\text { Mixed opinion. For } \\
\text { those who would have, } \\
\text { not with as many } \\
\text { resources or at speed } \\
\text { of commercialization. }\end{array}$ & Yes \\
\hline
\end{tabular}

There were no significant problems in implementing the qualitative assessments. Our approach to interview project managers rather than project staff was successful. All key participants were interviewed. The interviews went well; all necessary information was elicited from the interviewees. The interview process required more calendar time than expected; it often required 
several weeks to schedule a convenient interview time. This approach is clearly applicable to other ALM projects.

Table E.S.2. presents the results of the National Research Council indicator approach. The number of publications varied considerably based on the extent of university involvement and the preferences of private sector partners to publish or not to publish. At times, corporate cultures and Cooperative Research and Development Agreement requirements hinder private sector publishing. No projects had outside review panels, although the projects did receive review at the program level within DOE. The projects contributed to improving U.S. international competitiveness. The United States is leading in technology development in the continuous cast field. The United States is leading in R\&D for warm forming, but not in the variable binder. Finally, the United States auto makers are leading in the commercialization of the composite molding technology researched under that R\&D effort.

Table E.S.2. National Research Council indicators

\begin{tabular}{lcccc}
\hline \multicolumn{1}{c}{ Project } & $\begin{array}{c}\text { Number of } \\
\text { publications } \\
\text { produced. }\end{array}$ & $\begin{array}{c}\text { Does it use an } \\
\text { outside review } \\
\text { panel? }\end{array}$ & $\begin{array}{c}\text { Does it improve } \\
\text { U.S. } \\
\text { international } \\
\text { competitiveness? }\end{array}$ & $\begin{array}{c}\text { Is the United } \\
\text { States leading in } \\
\text { R\&D in this } \\
\text { field? }\end{array}$ \\
\hline $\begin{array}{l}\text { Continuous cast } \\
\begin{array}{l}\text { Aluminum } \\
\text { forming }\end{array}\end{array} \mathrm{l}^{\text {Composites }}$ & 5 & $\mathrm{~N}$ & $\mathrm{Y}$ & $\mathrm{Y}$ \\
Comped & $\mathrm{Y}$ & $\mathrm{Y}$ & $\mathrm{Mixed}$ \\
\hline
\end{tabular}

There were no significant problems in implementing this approach, either. The interviews and project materials provided sufficient information. Future applications of this approach should consider including patents, copyrights, software produced, and other tangible measures of intellectual achievements in an R\&D environment.

Table E.S.3 presents the results of the benefit-cost analysis, taking into account energy, environment, and cost reduction benefits. The project costs include both federal funding and private sector matching funds. In every case, the benefit-cost ratios are quite high, indicating high potential benefits for these projects. It must be noted, however, that several uncertainties are associated with these numbers, as is typical for benefit-cost analyses. First, the commercialization date, with and without federal support, and market penetration rates for each technology are uncertain. The analysis assumes dates for initial commercialization and market penetration rates that may or may not come true. Second, the projects reflect an uncertainty in the level of benefits associated with each new vehicle that contains new, lightweight materials. Third, uncertainties exist concerning the monetary values to be assigned to each benefit (e.g., technology. 
value of reducing $\mathrm{CO}_{2}$ emissions). Fourth, investment costs to be borne by the automobile manufacturers and their suppliers to implement the new technologies are not included in this analysis. This information was considered proprietary by the interviewees and not available for assessment. Finally, interviewees suggested that in-kind services were provided but tracking of these costs may not have occurred in every R\&D project covered in this report. The base, moderate, and high cases in Table E.S.3 represent low, medium, and high monetary values for energy and air pollution savings by the new vehicles.

Table E.S.3. Benefit-cost ratios

\begin{tabular}{lcccc}
\hline Project & $\begin{array}{c}\text { Project Cost } \\
\text { (\$ millions) }\end{array}$ & $\begin{array}{c}\text { B-C Ratio } \\
\text { Base Case }\end{array}$ & $\begin{array}{c}\text { B-C Ratio } \\
\text { Moderate Case }\end{array}$ & $\begin{array}{c}\text { B-C Ratio } \\
\text { High Case }\end{array}$ \\
\hline $\begin{array}{l}\text { Continuous cast } \\
\begin{array}{l}\text { Aluminum } \\
\text { forming }\end{array}\end{array}$ & 2.790 & 486 & 643 & 699 \\
Composites & 5.088 & 174 & 232 & 271 \\
\hline
\end{tabular}

Calculating the benefit-cost ratio required more time and effort than did the other two approaches. It is also plagued by more uncertainties. However, it provides one way to compare the relative benefits of the projects over the long term and explicitly addresses the benefits of commercializing technologies. This method presented no problems that would prevent its application to other ALM projects. Future efforts in this area might consider more sophisticated benefit-cost methods that more explicitly incorporate uncertainty analysis, such as optionspricing methods and probability assessments.

Another measure of benefit, calculated in terms of person-years gained by industry having access to federal R\&D funding, ranged from 18 to 70 person-years savings. The lower and upper range of benefits represents continuous cast and composites projects, respectively, consistent with the trend observed under the benefit-cost ratio.

In conclusion, this project successfully demonstrated the application of three approaches to estimating the benefits attributable to ALM R\&D projects. No significant barriers to their application were encountered. In combination, they provide a comprehensive report about project benefits. All three projects evaluated appear to have yielded significant benefits compared to their costs. 


\section{INTRODUCTION}

The purpose of this project is to identify and test methods appropriate for estimating the benefits attributable to research and development $(\mathrm{R} \& \mathrm{D})$ projects funded by the Automotive Lightweight Materials (ALM) Program of the Office of Advanced Automotive Technologies (OAAT) of the U.S. Department of Energy (DOE). The program focuses on the development and validation of advanced lightweight materials technologies to significantly reduce automotive vehicle body and chassis weight without compromising other attributes such as safety, performance, recylcability, and cost. The work supports the goals of the Partnership for a New Generation of Vehicles (PNGV). Up to thirty percent of the improvement required to meet the PNGV goal of tripling vehicle fuel economy and much of its cost, safety, and recylcability goal depend on the lightweight materials. Funded projects range from basic materials science research to applied research in production environments. Collaborators on these projects include national laboratories, universities, and private sector firms, such as leading automobile manufacturers and their suppliers.

It is important to assess the benefits attributable to R\&D projects. Such assessments can provide informative feedback to project managers and program directors. Results of assessments can be used to guide new R\&D funds and improve existing programs. In this case, benefit assessments can inform program managers about how well ALM projects are contributing to the goals of a effective federal government/private sector collaborative effort, the PNGV, to produce new, highly fuel efficient automobiles. Benefits assessments can also contribute to government-wide requirements for program evaluation, including R\&D projects, stipulated by the Government Performance and Results Act (GPRA) of 1993 (U.S. Congress, 1993).

Potential benefits derived from federal R\&D initiatives are quite numerous. These include advances in knowledge of fundamental science (Gelijns, Rosenberg, and Moskowitz, 1998; Fitzsimmons, 2001); improvements in technologies (Mowery and Nelson, 1999; Ernst, 1998; Chapman 1999); increased understanding and insights about policies, reduced production costs, improvements or modifications in products and processes (Hamilton and Sunding, 1998; Alston and Beach 1996); facilitation of collaborative efforts (Dietz, 1997; Torpey, 1994); educational support for undergraduate and graduate students, an overall human capital development measure (National Academy of Sciences, 1999); and increased international competitiveness for U.S. firms (Papadakis and Link, 1997). ALM projects have the potential to provide all these types of benefits.

Assessing benefits in a rigorous fashion is not a trivial exercise. The methodological issues appear to be as complex as those facing the researchers whose projects are to be evaluated. One major reason is that benefits may not be observed for many years after a project's funding ends (Ernst, 1998; Rouse, Boff, and Thomas, 1997). There may be unexpected benefits, just as there are unexpected consequences of many government programs (Gelijns, Rosenberg, and Moskowitz, 1998; Brown and Wilson, 1993). Benefits may not be monetary, e.g., increased knowledge even when a technology did not work (Nelson and Winter, 1982; Brown, 1998). Benefits as well as costs may be distributed among a wide variety of interested parties with differing values, concerns, and priorities (Rouse, Boff, and Thomas, 1997). These constraints 
grow in significance because they are observed in a diversity of R\&D spheres (Gibson and Rogers, 1994; National Research Council, 1994). There is also the issue of what to measure in the project evaluation.

This is not the first study to take up the challenge of estimating the benefits attributable to R\&D projects and programs. Section 2 begins with a review of the literature about methods to evaluate government programs generally and then specifically R\&D programs. The second part of this section presents the three methods applied by this research to evaluate the benefits of ALM R\&D projects. Section 3 describes the three ALM projects chosen to test the benefits assessment methods. The projects were chosen to provide a range of challenges characteristic of ALM R\&D projects. Section 4 presents the results of applying the methods to the three projects. Section 5 offers conclusions and suggestions for future research in this area. 


\section{METHODS}

\subsection{REVIEW OF COMMONLY USED BENEFIT ESTIMATION METHODS}

In 1996, the U.S. federal government spent $\$ 62$ billion on research and development (R\&D), including funds from the U.S. Department of Energy's budget (U.S. GAO, 1997). This public support of R\&D continues a tradition that began in the mid to late 1800s (Nelson, Peck, and Kalachek, 1967). The rationale for government R\&D expenditures include solutions to problems that are of general public interest (health, national security), an urgent need for private sector research and development support (agriculture), and the need for science and technology research beyond a particular public sector function or industry (the National Science Foundation's support for basic research) (Scherer, 1965; Nelson, Peck, and Kalachek, 1967). ${ }^{2}$ Because of the high degree of uncertainty on investment returns, the private sector often turns to the federal government for financial support (Scherer, 1965; Nelson and Winter, 1982; Gelijns, Rosenberg, and Moskowitz, 1998).

The literature on the evaluation of governmental programs, including $R \& D$, is quite extensive. Five basic elements of any government program should be considered during a program evaluation (Hendrick, 1994):
1. inputs,
2. processes,
3. outputs,
4. short-run impacts, and
5. long-run impacts.

Inputs are the resources used for the program (i.e., fiscal, staff). Processes are activities performed in providing services, such as number of grant applications mailed. Program outputs are immediate results of the processes (for example, number of grant applications reviewed). Short-run impacts would be the number of projects funded. Long-run impacts would be the increased knowledge level (an intellectual spillover) or in this case reduced energy consumption from use of lightweight vehicles. Although some scholars use the term impacts, others use the term outcomes. ${ }^{3}$

${ }^{2}$ We could also frame these within a market-failure economic context. For literature from this perspective, see for example Scherer (1965).

${ }^{3}$ Others have thought of program evaluation in simpler terms; evaluation of needs, processes, and outcomes (Posavac and Carey, 1985). This collapsed version in essence renames inputs as needs, combines processes and outputs, and does not specifically distinguish short-term versus long-term outcomes. 
When assessing the benefits of federal R\&D programs, the focus generally is on outputs and outcomes. In this context, outputs can be defined as immediate results from processes that clearly lead to outcomes. Outcomes are an assessment of the results of a program compared to its intended purposes. Outcomes of government spending either on R\&D or in broader terms seek to examine the impacts on the general public from expenditures of limited resources. In the latest round of government performance reform, the attention on outcomes seeks to determine whether positive results are being achieved for the general public or whether there is a positive difference in people's lives from the federal government's involvement in programs (Radin, 1998; U.S. GAO, 1997; NAS, 1999).

There are numerous methods or indicators that have been used in previous studies to assess outputs and/or outcomes of federal R\&D expenditures. These include:

1. Economics. Economic techniques are frequently used by federal agencies in their evaluations of R\&D investments. These techniques may take different forms, but the most common are benefit-to-cost ratio, internal rate of return, present value of net savings, and net benefits (e.g., a measure of rate of return). A more recently used economic measure is from an efficiency gain perspective. Here consideration is given to private sector investments needed to achieve a certain level of technical capability. It seeks a response to "In the absence of . . . [federal funding] . . ., what would your company have had to do to obtain the same level of technical capability that it currently has, and what resources over what time period would have been needed to pursue such an alternative" (Link and Scott, 1998, page 14). It is another effort to measure return on investment. Economics is a commonly used tool as the premises for federal involvement in R\&D are improvements in products and processes leading to lower production costs, increased international competitiveness, and technological advancement, measured in economic terms.

There are, of course, weaknesses to economic techniques. Such weaknesses include insufficient data on benefits and/or costs, time lags between R\&D funding and beneficial outcomes, marginal rate of return (how much return for an extra dollar of investment), and complexity of innovation with multiple inputs required for full adoption (NAS, 1999; U.S. GAO, 1997; Link, 1993; Rouse, Boff and Thomas, 1997; Brown, 1998). Regardless of the weaknesses, economic techniques are frequently used.

2. Bibliometrics. Bibliometrics is the analysis of output from research using publication-based data. Forms of bibliometrics include publications, citation counts, presentations at conferences, publication of conference proceedings, and technical reports that are publicly available (e.g., from national laboratories). Their use has been accepted as a proxy for R\&D benefits because of the difficulties in evaluating R\&D activities (Melkers, 1993).

Bibliometrics can serve as a source of information on "measurement of scientific output, the extent of knowledge transfer and the impact of research, and an approximation of the links between science and technology" (Melkers, 1993, page 49). Its use has been expedited by the creation of the Science Citation index.

These metrics serve as a quantitative, well understood proxy for how the research is viewed. Use of bibliometrics is based on the assumption that a researcher's work is valuable when judged so 
by a researcher's peers. Acceptance of a peer-reviewed paper occurs after a traditionally rigorous evaluation process of its merit. Citation counts can appear in patent applications, as well as other research in the field. Patents can show a nation's technological strength and are a signal of innovation from an R\&D project. Brown (1998) reports a strong relationship between scientific papers cited on patent applications and federally funded R\&D.

Limitations on use of publications as a tool include measurements of quality versus quantity, challenges in comparisons across disciplinary fields, and the increasingly important role of interdisciplinary research seeking appropriate publication outlets. Patents vary across technologies and industries, which hinder comparisons among projects.

3. Case studies. Case studies can focus on the institutional, organizational, and technical factors that influence research processes, and can provide in-depth insights into the success or failure of a research project. They can clearly identify qualitative issues, such as degree of collaboration, training for junior researchers, and the dynamics within a specific setting that can be used to judge success. Traditionally, case studies have been used to gauge the linkages between R\&D and economic innovation and to judge whether R\&D projects meet policy objectives established for a group mandated to address linkages between R\&D and the economy (Kingsley, 1993). A commonly cited justification for using case studies as a research method in general is due to a lack of clearly understood theory to associate with results. Specifically, for $R \& D$, the uncertainty lies in how different types of R\&D projects affect economic growth (Yin, 1984; Kingsley, 1993). Case studies of federal R\&D and economic growth became popular in the 1960s.

Yin (1984) summarized the strengths of case studies as addressing why and how an event occurs, providing a rich set of information on nonquantifiable relationships that exist among variables included in a study, and exploring topics unhindered by constraining theory. Of course, there are challenges to the use of case studies. It is difficult to generalize findings from case studies to a larger setting, and the rigor of the researcher can be challenged in how the narrative form of the information is organized and analyzed. Case studies can also be expensive to conduct.

4. Peer reviews. Peer review is an evaluation method where an independent panel of technical experts judges R\&D results. The evaluation is based on the experts' assessment of the quality of the research. It is a self-evaluation in the sense that reviewers come from the researcher's primary disciplinary field. Its premise is that those most knowledgeable in the field can gauge research agendas and the qualifications of those conducting the research. Peer review is used by many federal agencies in project funding decisions, and it is gaining support for use in evaluating R\&D results.

Criticisms levied against this technique include that it promotes "conservatism" and elitism among researchers (Bozeman, 1993, page 81). Who is defined as an expert can raise questions about bias and favoritism. Even the Committee on Science Engineering, and Public Policy (COSEPUP) of the National Research Council, which emphatically recommends the use of peer review (or expert review) when evaluating government R\&D programs, has noted that "legitimate concerns ... have been raised about expert review (such as conflict of interest, independence, and elitism)" (NAS, 1999, pp. 32-33). 
5. Retrospective analyses. Retrospective analyses are long-term evaluations of federal R\&D benefits. They allow a systematic linkage between funding and outcomes with special attention on spillovers and spin-offs. They are similar to case studies in that they trace historical events. As such, they can incorporate the temporal dimension mentioned elsewhere in this report.

As with case studies, retrospective analyses can be expensive. Moreover, such analyses cannot assist in assessing short-term outcomes (NAS, 1999).

6. Benchmarking. Benchmarking has become an often-used tool over the last several years for evaluating performance from a public administration perspective. Appropriate indicators are compiled to judge a program (albeit, state, local, federal, or international) against its closest competitors. Hence, in this context, indicators would assess whether the U.S. R\&D is cutting edge. The challenge in benchmarking is finding comparable indicators and similar datacollection methods. Moreover, its use to date generally has been on programs outside the R\&D field.

Each of these methods has strengths and weaknesses, as summarized in Table 2.1. Regardless of which method or methods are chosen, the challenge in evaluating R\&D is the lag between expenditure and actual realization of outcomes.

Application of these measures can be conducted through statistical applications such as interrupted time series comparison group, pretest-posttest comparison group, or singleinterrupted time series (see Brown, Curlee, and Elliott, 1994; Langbein, 1980; Babbie, 1998; Posavac and Carey, 1985). The method or indicator ultimately chosen should be valid, reliable, understandable, timely, comprehensive, sensitive to data collection and availability, and focus on controllable facets of performance (Ammons, 1995; Rossi and Freeman, 1985; Fischer, 1995). The technique should carefully delineate whether the researcher is evaluating input, process, output, short-run outcomes, and long-term outcomes. If the researcher is examining outcomes, it should be remembered that measuring outcomes of governmental programs generally takes many years as outcome is seldom observed in the short-term. Nevertheless, an assessment of expected benefits is warranted. 
Table 2.1. Evaluation methods commonly used

\begin{tabular}{|c|c|c|}
\hline Method & Strength & Weakness \\
\hline Economics & $\begin{array}{l}\text { Quantitative; shows monetary } \\
\text { benefits of research. }\end{array}$ & $\begin{array}{l}\text { Has not traditionally measured } \\
\text { social benefits; productivity lag } \\
\text { makes this difficult to measure; may } \\
\text { not be directly traceable to inputs. }\end{array}$ \\
\hline Bibliometrics & $\begin{array}{l}\text { Quantitative; patents can be reliable } \\
\text { indicator of nation's technological } \\
\text { strength in product development. }\end{array}$ & $\begin{array}{l}\text { Does not necessarily capture quality; } \\
\text { difficult to compare across } \\
\text { disciplines. }\end{array}$ \\
\hline $\begin{array}{l}\text { Peer review or } \\
\text { subjective } \\
\text { assessments }\end{array}$ & $\begin{array}{l}\text { Well-understood by academics; can } \\
\text { provide rigorous evaluation of } \\
\text { research; procedure generally already } \\
\text { established in federal agencies. }\end{array}$ & $\begin{array}{l}\text { Dependent on quality of peer review } \\
\text { panel; subjective bias may occur; } \\
\text { may be expensive; is considered } \\
\text { elitist; conflict of interest among } \\
\text { researchers may occur. }\end{array}$ \\
\hline Case studies & $\begin{array}{l}\text { Provide extensive qualitative and in } \\
\text { some situations quantitative in-depth } \\
\text { insights into project; generally focus } \\
\text { on processes. }\end{array}$ & $\begin{array}{l}\text { Difficult to generalize to broader } \\
\text { program area; cannot compare } \\
\text { across programs. }\end{array}$ \\
\hline $\begin{array}{l}\text { Retrospective } \\
\text { analyses }\end{array}$ & $\begin{array}{l}\text { Useful for identifying linkages } \\
\text { between federal expenditure and } \\
\text { long-term benefits. }\end{array}$ & $\begin{array}{l}\text { Cannot be used as short-term } \\
\text { evaluation tool. }\end{array}$ \\
\hline Benchmarking & $\begin{array}{l}\text { Comparison across programs and } \\
\text { countries. }\end{array}$ & $\begin{array}{l}\text { Difficult to find comparable } \\
\text { measurements and data collection } \\
\text { efforts. }\end{array}$ \\
\hline \multicolumn{3}{|c|}{$\begin{array}{l}\text { Source: Compiled from NAS (1999); Geisler (1995); U.S. GAO (1997), Link and Scott (1998); } \\
\text { Scherer (1965); Griliches (1998); Hyde, Newman, and Seldon (1992); Chapman (1999); } \\
\text { Fitzsimmons (2001); Rossi and Freeman (1985); Fischer (1995); Ammons (1995); Brown (1998); } \\
\text { Bozeman and Melkers (1993). }\end{array}$} \\
\hline
\end{tabular}




\subsection{METHODS USED FOR BENEFIT ESTIMATION}

Guided by the above review, we chose three approaches to assessing the benefits attributable to ALM projects: qualitative assessment, National Research Council indicators, and benefit-cost analyses, including calculating a benefit-cost ratio. This combination addresses all-important aspects of the benefits of R\&D projects and supports recent recommendations to use multiple evaluation criteria (MacRae and Whittington, 1997; Langbein, 1980; Fischer, 1995). The qualitative assessment addresses short-term project outcomes at the project level. The indicators address standard measures associated with the quality of research projects. The benefit-cost analysis addresses both short-term and long-term benefits associated with commercializing new technologies. Since ALM projects encompass both the creation of new knowledge and the commercialization of new technologies, both the indicator and benefit-cost approaches are appropriate. Each approach is outlined below.

\subsubsection{Qualitative Assessment}

This approach focuses on the subjective judgments of project participants concerning the benefits attributable to the projects. Were the project objectives met? Was new knowledge gained? Were technologies improved? What is the potential for commercialization of the new and/or improved technologies? Was the project a worthwhile investment of time and money? Did the project result in improved professional collaborations? Would the project have been undertaken by the private sector without federal assistance? What cost sharing contributions did the private sector make to the projects? These and other questions elicit the qualitative and intangible benefits of the R\&D projects.

Qualitative assessments most closely match the case studies approach from a methodological perspective. The case study approach has been used to evaluate U.S. Department of Defense research since the 1960s (see Kingsley, 1993). Regardless, qualitative assessments are not common in R\&D evaluation among other federal programs. We included this as an evaluation method, however, because success of a project may hinge on those issues that cannot be valued easily on a monetary basis. It also supports the notion of using multiple methods for evaluations.

Qualitative assessment requires that key participants (e.g., project managers) be interviewed, typically over the phone but in face-to-face settings if convenient. Also, project documents should be reviewed. These include progress reports, draft and final project reports, conference presentations, and conference and journal papers. The success of the approach depends on the willingness of key participants to be interviewed.

\subsubsection{National Research Council Indicators}

The second approach chosen stems from the work of the National Research Council cited in the previous subsection on its evaluations by COSEPUP of federal R\&D programs. Three indicators were adopted from this work:

- the number of publications coming out of the research projects, 
- the role of review panels in guiding and assessing the projects, and

- the participants' identification of an appropriate indicator for measuring leadership in the international field.

Fitzsimmons (2001) demonstrated publications, presentations, and patents in a review of PNGV's Cast Light Metals and Rapid Tooling projects, American Textile Partnership, and National Machine Tool Partnership. Link (1995) used publications and presentations in his evaluation of the printed wiring board joint venture and short-wave sources for optical recording, a joint venture funded under the Advanced Technology Program at the National Institute of Standards and Technology, U.S. Department of Commerce. The U.S. Army Research Laboratory uses number of refereed journal articles/proceedings, technical reports, and test reports in its evaluations (Brown, 1996). Geisler used publications and patents in his analysis of two national laboratories (Geisler, 1995). Thus, there is ample precedent for using this indicator to evaluate ALM R\&D projects. Also, as mentioned above, review panels are a standard means of assessing the quality of R\&D.

The final indicator is specially designed for projects that also have the potential to improve U.S. competitiveness in a particular field. Information for these indicators is straightforward, collected from interviews with project participants and review of project materials.

\subsubsection{Benefit-Cost Analysis}

We chose benefit-cost analysis as our third assessment method. Benefit-cost analysis is an accepted tool in developing policy alternatives and for conducting program evaluations (Fischer, 1995). It allows for easy comparison of the benefits that would be achieved under a program versus the costs of that achievement. It is transparent in that benefits and costs can be clearly identified. Hence, it is a clearly understood tool. It is also frequently used as a program evaluation method where it is important to consider preliminary long-term benefits.

Applications of benefit-cost methods to evaluate R\&D are numerous. The National Institute of Standards and Technology (NIST) has used present value of net benefits, present value of net savings, benefit-to-cost ratio, savings-to-investment ratio, and adjusted internal rate of return as economic measures in its analyses of: cybernetic building systems in office buildings; new standards for residential energy conservation; improved asphalt shingle for sloped roofing; and construction systems integration and automation technologies in industrial facilities (Chapman, 1999; Chapman and Fuller, 1996; Chapman, 2000). Social rates of return on public agricultural R\&D have been demonstrated for years (Alston, Norton, and Pardey, 1995; Alston and Beach, 1996). Hamilton and Sunding (1998) used a form of economic analysis (production functions under imperfect competition) on public investments in agriculture. Martin, Gallaher, and O'Connor (2000) calculated benefit-cost ratio, social rate of return, and net present value in an evaluation of NIST's standard reference materials for sulfur in fossil fuels. Marx, Scott, and Fry (2000) calculated benefit-to-cost ratio and net benefits for NIST's investments in primary calibration services. Benefit-cost analysis has been used for evaluation of public R\&D investment in forestry (Hyde, Newman, and Seldon, 1992). The Cockpit Automation Technology (CAT) program of the U.S. Air Force Armstrong Laboratory, U.S. Department of Defense was reviewed within a benefit-cost framework (Rouse, Boff, and Thomas, 1997). Papadakis and Link 
(1997) used cost-benefit in measuring the impacts of new business starts-ups on plasma spray technology and in measuring new or improved products/processes with polycrystalline diamond compact drill bit knowledge from Sandia National Laboratories. Link, Teece, and Finan (1996) calculated a benefit-cost ratio in their evaluation of SEMATECH. Link and Scott (1998) estimated internal rate of return, implied rate of return, and ratio of benefits-to-costs for eight programs financed through the Advanced Technology Program, U.S. Department of Commerce.

It is assumed here that the primary benefit of the projects is to bring new technologies to the automotive market. Commercialization of the technologies, in turn, produces measurable secondary benefits with respect to reductions in energy use and emissions of air pollutants (which are explained more in Section 3). It is assumed that federal support for these projects accelerated the research and development of these technologies and have or will hasten their commercialization. In other words, it is assumed that these technologies would have eventually made it to the market without federal support, but many years (and much energy use and air emissions) later. Therefore, our methodology attributes benefits to the projects that represent the energy and environmental benefits that begin accruing at the time of commercialization with federal support, $\mathrm{t}_{0}$ until the time when the technologies would have been commercialized absent

federal support $t_{1}$. Benefits are stopped being accrued to the projects as such time that the market penetrations of the technologies under the assumption of no federal support catch up to the market penetrations of the technologies with federal support. This approach is taken so as not to overly attribute benefits to the projects.

Costs considered include federal and private sector expenditures on the projects. Cost of commercializing the technologies, which may include equipment costs, training costs, marketing costs, etc., are not included for two reasons. Most importantly, it is assumed that these costs would have been borne by industry at some other point in the future. Secondly, these costs were not available from the companies, as these costs are business confidential.

There are two components to in our attempt to monetize benefits and costs, calculating a benefitcost ratio and capturing person-year savings by industry. Each is discussed below.

\section{Market Penetration}

The first effort to monetize benefits and costs pertains to benefits from the market penetration of new vehicles built with lightweight materials related to the projects under consideration. This component of the method requires market penetration forecasts that address when the new technologies will be commercialized both with and without federal support, what vehicle components and/or parts will be produced by the new technologies, and how many vehicles will be sold each year with these new, lightweight components. Also required is the identification of benefits attributable to each new vehicle (e.g., energy savings, environmental emission reductions), as compared to today's vehicles, the magnitude of the benefits, and the monetized and discounted values of these benefits. These are challenging tasks that rely on informed judgements (e.g., from key participants for market forecasts), engineering studies (e.g., for energy savings), and economic analyses (e.g., to value reductions in $\mathrm{CO}_{2}$ emissions). Fortunately, the literature contains most of the engineering studies and economic analyses needed for components of the benefit-cost analysis of ALM projects. 


\section{Counterfactual Analysis}

The second monetary component in our benefit-cost analysis included in this research pertains to what resources the private sector would have had to expend to achieve the same results of the research projects without federal funding. The counterfactual method is clearly an evaluation of program efficiency (cost per research project, Ammons, 1995). That is, it is a "determination of the relative efficiency of public versus private investment" in technology development (Link and Scott, 1998, p. 16). Counterfactual benefits can be thought of as cost avoidance (for example, a decrease in transaction costs) by the private sector due to the availability of public R\&D funds.

Marx, Scott and Fry (2000) considered transaction costs that would have been occurred by the private sector in the absence of federal funding in an evaluation of NIST's R\&D efforts in primary calibration services. Link and Scott (1998) have reviewed counterfactual analysis in their evaluations of the Advanced Technology Program (ATP) of the U.S. Department of Commerce. Such information can be gained from interviews and project materials.

\section{Benefit-cost Ratios}

The market penetration benefits produce monetary benefit estimates, including energy, environment, and cost reductions for each project. Then, the benefits are divided by the project costs to calculate benefit-cost ratios. As discussed earlier, the benefits for a project are defined to be those attributed to the accelerated commercialization of its technology made possible by federal support, compared to when the technology would have been commercialized without federal support. Projects are deemed acceptable if the ratios are greater or equal to 1.0. Projects typically need much higher ratios to be deemed successful. The counterfactual analysis follows the presentation of the benefit-cost ratios.

\subsection{SUMMARY OF METHODS}

Table 2.2 summarizes the four methods used in this research to assess the benefits attributable to ALM projects. The set of methods allows the assessment of qualitative factors and the development of quantitative benefit measures. All the methods have precedent in the literature. Together, the methods can provide comprehensive insights into the short- and long-term benefits of the R\&D projects. 
Table 2.2. Benefits evaluation methods used in this research

Method

Description

Qualitative assessment

National Research

Council indicators

Benefit-cost analysis market penetration
Assessment of participants' subjective views about the benefits attributable to the projects.

Quantitative measurement of publications, qualitative assessment of role of review panels, qualitative identification of benchmarks to gauge international competitiveness.

Quantitative measurement of benefits associated with the accelerated market penetration of new, lightweight vehicles whose production benefited from the research projects; measures include energy savings and air pollution emission reductions.

Quantitative measurement of cost savings by industry with access to federal R\&D funds, quantitative measurement of time savings by industry through access to federal R\&D funds. 


\section{AUTOMOTIVE LIGHTWEIGHT MATERIALS PROJECTS}

As mentioned in the Introduction, the purpose of this project is to identify and test methods to evaluate the benefits attributable to R\&D funded by the ALM Program of the OAAT. The goal of the ALM Program is to provide validated advanced materials and manufacturing technologies that can be realized in commercially viable automobiles. OAAT was established in 1996 to consolidate all of DOE's light duty vehicle technology R\&D activities. Its research focuses on eliminating serious technological barriers to the development of energy-efficient automotive technologies. OAAT's focus is on developing cleaner and more energy-efficient technologies for automobiles of the future. The main thrust of OAAT efforts is the development of technologies in support of the PNGV, a presidential initiative that combines resources of the major U.S. automakers and various federal agencies to:

- Significantly improve national competitiveness in manufacturing by exploring technologies that reduce the time and cost to design and manufacture vehicles;

- Apply innovations, when they are commercially viable, to conventional vehicles; and

- Develop a vehicle with up to three times the fuel economy of today's conventional, mid-sized sedans, while achieving improved recyclability and maintaining comparable performance, utility, safety, and cost of ownership.

The ALM funds numerous projects each year. In this report, a few recent projects were selected to test and evaluate the three benefits estimation methods discussed in Section 2.2. Three R\&D projects from PNGV were chosen for this pilot evaluation: Low-Cost, Continuous Cast Aluminum Sheet; Advanced Forming Technologies for Aluminum; and Manufacturing of Composite Automotive Structures. These projects were chosen because they represent a range of benefits' evaluation situations. The first project resulted in an improved process that may be commercialized. The second project is on going and has two distinct components. The third project has yielded an improved technology that has been commercialized by two of the three U.S. automakers; the completed project was composed of numerous complementary projects. Each is discussed in more detail below. It should be emphasized that evaluation of this small number of projects does not constitute an extensive evaluation of all ALM projects or of the OAAT.

\subsection{LOW-COST, CONTINUOUS CAST ALUMINUM SHEET}

The specific objectives of the project were to (1) validate that the continuously cast sheet met the specifications for auto body applications, and (2) estimate cost differential between continuous cast and ingot process. The key partners involved in this project were Reynolds Metals Corporation (prior to its purchase by the Aluminum Company of America), Commonwealth Industries, Los Alamos National Laboratory, and the U.S. Automotive Materials Partnership of U.S. Council for Automotive Research (USCAR). 
Decreasing vehicle weight is one of the most effective ways of increasing automobile fuel efficiency, second only to increasing powertrain efficiency. Although aluminum offers the greatest potential for weight savings-up to 50 percent in automotive body-in-white and closure panels applications-its costs are 10 to 50 percent higher than those of comparable steel parts. Aluminum sheets for automotive applications are expensive. They are typically produced by direct-chill casting of large ingots, which are then hot-rolled from a thickness of nearly 24 inches down to between 0.25 inches and 0.08 inches. The three-year automotive lightweight materials project on the low-cost aluminum alloy sheet, started in 1996, examined the cost savings derived from reducing the number of rolling steps and heat treatments necessary to form sheet product.

This project demonstrated that cast product-typically 0.75 inches to 0.875 inches thick-can be directly hot-rolled to final thickness without additional rolling passes or intermediate heat treatments (a similar process used today for beverage can stock). The process developed uses a combination of alloys and thermal treatments to produce a continuous cast and hot-rolled 5754 alloy aluminum sheet with thicknesses of 0.04 inches to 0.12 inches that has properties as good or better than those of 5754 sheet produced by the ingot method. Five complex full-scale automotive parts including a dash panel pan were successfully stamped from 0.04 inches and 0.08 inches by hot rolling and cold rolling. Demonstration of this technology has so far been limited to non-heat treatable 5000 series aluminum used for inner closure panels and structural automotive applications. Preliminary cost estimates indicate that the conversion from direct-chill casting to continuous casting would reduce the price of the sheet product by 10 to 25 percent. With the low prices for primary aluminum, the cost of 5754 sheet could fall near or below the $\$ 1 / 1 b$ target that would make aluminum competitive with steel for more automotive applications. It is also anticipated that due to the size and location flexibility offered by continuous casting, recycling of both plant and post-consumer scrap would also be facilitated. Some level and type of impurities, such as magnesium, have been shown to have a minor effect on mechanical properties and may be tolerated without significant performance loss.

\subsection{ADVANCED FORMING TECHNOLOGIES FOR ALUMINUM}

In this project, a team led by Alcoa investigated technologies leading to improvements in the conventional automotive sheet forming/stamping process and the development of alternative economical forming processes and/or methods for automotive component manufacturing that offer weight reduction opportunities and enable aluminum to become more cost effective. Two methods-binder load control and warm forming-were examined for the improvements in the formability of aluminum sheet (without wrinkling and/or tearing). Project participants included Alcoa, DOE, USCAR, and Michigan Technological University, as well as aluminum part manufacturers.

The force on the edge of a stamping part (binder force) regulates the flow of material into the die so that no wrinkles or splits occur. In the binder control method, by varying the force on the blank (a sheet of flat metal) during the stamping process, the window (percentage of blank size 
that can be used) for producing good parts may be enlarged. This technique would help in reducing production problems and process development time and in improving quality. Initially, the variable binder load technique was demonstrated for two laboratory parts. It used the restraining force control unit and provided valuable information about how to design the variable binder loading and how to simulate the process for initial binder load trajectories. The effect of the variable binder on the part condition for the 37 liftback panels formed was demonstrated in October 1999 at Troy Design and Manufacturing.

The other advanced forming method for aluminum aimed to evaluate the functional improvements in forming complex automotive aluminum parts at elevated temperatures that cannot be produced by conventional stamping processes. Due to aluminum's inherent lower formability, single parts need to be split into multiple parts or additional dies, resulting in increased stamping complexity and an eventual increase in the overall part costs. Properly designed and implemented warm forming techniques have the potential to improve both the intrinsic and extrinsic formability of aluminum, permit aluminum to be substituted for many steel body components with rather minor modifications of the tooling, and increase the ability of the materials to produce more complex shapes. Parts can be formed in one operation, compared to two for steel. In addition, die can operate in a production-like environment at high-volume rates. Optimized temperatures and temperature profiles for warm forming were developed for a few 5000-series aluminum alloys. This technology was successfully demonstrated on 70 complex, full-size automotive panels for the Dodge Neon door inner panel.

\subsection{MANUFACTURING OF COMPOSITE AUTOMOTIVE STRUCTURES}

This project is one of the validation activities, called focal projects, developed between 1995 and 1999 that demonstrate ALM program goals and reduce the lead time to bring new technology into the marketplace. These projects focus on specific classes of materials and nonproprietary components and are done jointly by DOE and the Automotive Composites Consortium (ACC) of USCAR. The goal of this particular project was to develop and demonstrate rapid manufacturing technology, material performance data, and reliable assembly methods needed to produce large and complex composite automotive structures. This project demonstrated the feasibility of producing composite pickup truck boxes-at a rate of one every 4 minutes-that meet all performance criteria and weigh 25 percent less than and cost no more than a comparable steel structure.

One key to commercial application of large automotive composite structures in this project has been the Programmable Powdered Preforming Process, or P4, invented by a subsidiary of Owens Corning Fiberglass (through laboratory demonstration of the technology). The process involves choppers mounted on robots that spray short strands of glass fiber onto a screen to make preformed shape. Once the preform is made, it is lifted out and placed in a mold where the preform is injected with a liquid resin that solidifies to make a completed composite part. The 
compatible P4 preform and structural reaction injection molding (SRIM) resin injection processes have demonstrated the capability for the manufacture of composite structures that have a high degree of part consolidation and, thus, improved cost effectiveness relative to stamped metal structures.

Preform technologies have tremendous potential in structural composite applications. Although SRIM has been developed for several years, it has not been applied to large automotive parts. Use of P4 is a new technological development in this R\&D project as applied to automotive parts. Ford is using P4 for three large, semi-structural components in its low-volume Aston Martin Vanquish model. GM has chosen this technology for the composite pickup boxes that are available as an option on its model year 2001 Chevy Silverado. The Silverado's box is molded using 50-percent glass-filled polyurethane, that is 50 pounds lighter, and has a tailgate that is 15 pounds lighter than its steel counterpart. The one-piece composite bed eliminates the need for and thus the cost of a separate liner (estimated to cost about $\$ 250$ and needs replacement every two to three years), reduces the number of box parts from 12 to just 1 , simplifies vehicle assembly, resists dents and scratches, and needs no painting (the color is molded in). The bed is bonded with adhesives to the pickup truck frame.

In addition, Delphi Automotive Systems is planning to use this technology for automotive bumpers. DOE and ACC in their ongoing Focal Project III, which focuses on carbon fiber composite intensive body-in-white applications, is currently planning adaptation of the P4 process to carbon fiber applications. The $\mathrm{P} 4$ process is already being used with carbon fiber in an evaluation program sponsored by the Air Force for aerospace structures (Reinhart 1999). Compared to conventional composite fabrication methods (e.g., hand lay-up, hat stiffeners), the $\mathrm{P} 4$ process may reduce costs as much as 85 percent for composite structures.

Table 3.1 lists seven ALM projects that contributed to the successful demonstration of a large commercialized automotive composite structure. Contributions by the other projects range from joining of parts, to the understanding of failure mechanisms of glass fiber reinforced composite parts. They helped in technology developments in the durability characterization of polymer composites, adhesive materials, and nondestructive testing methods. Several ACC partner companies, supplier companies, national laboratories, and universities participated directly in the project featured here or in supporting projects, and some provided cost sharing to this project. Noted in parentheses is the share of the costs of these projects that are used in the benefit-cost analysis discussed in Section 4.3, based on the benefits that these projects contributed to the specific project under consideration. Besides the second and last projects, all others in this list were matched $100 \%$ by the industry contributions. 
Table 3.1. Projects that contributed to manufacturing of automotive composite structures

\begin{tabular}{ll}
\hline \multicolumn{1}{c}{ ALM Project Name } & \multicolumn{1}{c}{ Contribution } \\
\hline $\begin{array}{l}\text { Adhesive bonding technologies for } \\
\text { structural composites }\end{array}$ & $\begin{array}{l}\text { Adhesive development, testing of simulated joints, } \\
\text { development of test methodologies and methods for } \\
\text { assessment of durability under creep, fatigue, and } \\
\text { environmental exposure }(50 \%) .\end{array}$ \\
$\begin{array}{l}\text { Adhesive modeling } \\
\text { Durability of lightweight composite } \\
\text { structures }\end{array}$ & Maint design (50\%). \\
$\begin{array}{l}\text { Rapid nondestructive evaluation evaluation and selection (10\%). } \\
\text { Nondestructive evaluation } \\
\text { techniques for on-line inspection of } \\
\text { automotive structures with adhesive } \\
\text { joints }\end{array}$ & Bond, joint, and material integrity evaluation (10\%). \\
Slurry process development & Slurry preforms for the tailgate considered initially \\
Slurry modeling & (100\%). \\
\hline
\end{tabular}





\section{RESULTS}

\subsection{QUALITATIVE ASSESSMENT}

This approach entails obtaining subjective assessments from participants about the benefits of each project described in Section 3. To accomplish this task, project participants were interviewed. The general interview process is described immediately below. The results of the interviews about each project are presented in Sections 4.1.2 through 4.1.4. A summary of the results of the qualitative assessment are presented in Section 4.1.5.

\subsubsection{Interviews}

We conducted extensive telephone interviews with key participants in each research project following a standard set of prepared questions. Key participants included project managers and their assistants. Other project staff and higher level managers were not interviewed. This is because the project managers possess the detailed yet strategic knowledge about the projects and potential technology commercialization needed for the evaluation; project staff may not have strategic knowledge whereas the higher level managers probably are not aware of important project details. Additionally, if there is information relevant to the evaluation that a project manager does not know or possess, we expect the project manager will refer us to the proper person or resource. Lastly, focusing on project managers reduces the number of interviews needed.

Initial contact set up a mutually convenient time for the interview. Interviews lasted an hour and a half on average. Two project staff participated in each interview to make sure that complete notes were taken. In many instances, more than one project participant joined the interview. We interviewed a total of 11 key people. In some instances, the interviewees had the summary of the interviews reviewed by additional staff members in their organizations to ensure full presentation of the results of the R\&D efforts. Before each interview we reviewed prepared progress reports on each $\mathrm{R} \& \mathrm{D}$ project, written material provided by the interviewees, and published papers that resulted from the $R \& D$ efforts.

A written summary of each conversation provided an opportunity for interviewees to review the summary. The summaries were amended based on participant feedback. In all instances, the interviewees were granted confidentiality, a standard in survey research (Folz, 1996). Thus, no responses in this report are attributed directly to any interviewee. Instead, the responses are phrased in more generic terms, such as "a representative from one of the three U.S. automakers concludes that...." 
Certain types of information were identified as strictly proprietary by the private sector representatives, whether raw material suppliers, parts suppliers, or automakers. One representative considered cost comparisons confidential, while all private sector interviewees regardless of their role in a project declined to share corporate business plans, costs of equipment, additional employee training, changes in utility costs, or other input costs that will be realized by the three U.S. automakers or their suppliers if a new technology evolving from these $\mathrm{R} \& \mathrm{D}$ projects is adopted for manufacturing use. This proprietary nature prevailed across all case studies.

\subsubsection{Low-cost, Continuous Cast Aluminum Sheet Project}

The objectives of this project aimed to: (1) validate that the continuously cast sheet met the specifications for auto body applications and (2) estimate cost differential between continuous cast and ingot process. Both objectives were met to the satisfaction of participants.

There was disagreement among those interviewed on whether adoption and commercialization of the process would occur within the automotive sector. The question is not whether the continuous casting process can work but if and when the automobile manufacturers will make the strategic decision to mass produce vehicles built with substantial amounts of aluminum. In any case, one participant responded that the "real" success of the project was the ability not only to have the continuous cast demonstrated at a laboratory level, but also to have a full scale demonstration that proved successful. Another participant noted that the ability to attach monetary values to the costs of manufacturing continuous cast sheets and compare those with the ingot process was another successful aspect of the project. He went on to note that the ability to share that information with primary customers, and the fact that the primary customers were pleased with the results, was the best way to define success from a private sector perspective.

None of the participants interviewed would have participated in the three-year project without DOE funding. Two of the companies involved in the project were involved in acquisitions, one immediately before the DOE project, the other during the project. One firm said that it may have participated in the first year of the research project, but without DOE funding would not have participated in the second or third year. Another firm said that it would not have participated at all without DOE funding because the firm simply did not have the resources to devote to the project. The interviewees agreed that collaborative efforts were enhanced.

With regard to whether the research project will lead to increased competitiveness for those receiving funding, the answers were mixed. One company may not pursue the continuous cast line from a corporate strategic planning viewpoint, while another was more optimistic that it may have the capabilities to meet some level of demand from the auto sector. The latter company had considered continuous cast as an area for market growth, but declined to proceed without the needed resources to implement the project. The interviewees indicated that barriers to implementation of the continuous cast sheet by the auto industry included: consumer concerns about safety, lack of consumer demand for lighter weight vehicles, and cost of aluminum versus 
steel. One representative of the auto industry indicated his company would review the potential use of continuous cast as one option, among many, in future manufacturing design discussions.

\subsubsection{Advanced Forming Technologies for Aluminum Project}

This project was divided into two tasks: process/press optimization and warm forming. The objective for the optimization project was to improve the aluminum sheet metal stamping process through development of a method of controlling the flow of metal into the tooling cavity during the stamping process, with application of variable binder loads. Laboratory demonstration was successful in preventing wrinkling and/or tearing of the aluminum from the variable binder process. A full-scale demonstration is planned for Phase II of this project.

The objective for the warm forming was to demonstrate the feasibility of using the warm forming technology in the manufacture of aluminum automobile parts. The objective was met; it is feasible to use warm forming in large automotive structures. However, technical issues identified are being addressed in Phase II. Specifically, more analysis is needed concerning lubricants and temperature controls of the dies during the warm forming process. In addition, a cost analysis will be performed in Phase II.

The interviewees concluded that Phase I was successful on both tasks. However, the degree of success should be set in a context that technical issues identified in the process may prevent adoption of either of these technologies in the near-term. For example, Phase II of the warm forming is a four-year effort. Even if the technical issues are resolved, it may be another three to five years before commercialization is accomplished, depending on the cycle time of the automobile sector. One interviewee concluded that the success of both projects in Phase I could be measured as bringing everyone in the supply chain to the same level of knowledge of the processes, their potential, and their current limitations. When asked whether that can be judged as successful, he replied "moderately successful" although he agreed that bringing everyone to the same knowledge level was a key step in gaining access to funding for Phase II. Another representative from the U.S. automakers considered limitations identified in Phase I as simply part of the research process. Everyone agreed that work in Phase II may assist in demonstrating the viability of these technologies.

Two interviewees from the auto industry indicated that the company would have engaged in the Phase I research without DOE funding, although another private sector participant indicated that it would not have participated. With regard to one of the two auto makers that would have pursued this endeavor, the interviewee pointed out that the fiscal contributions would not have been available to have engaged in the breadth of research, personnel commitment, or time frame. He mentioned that for this R\&D to proceed would have required a large fiscal commitment that

in his opinion none of the big three automakers would have invested on their own. He noted that with market pressures on auto makers and other priorities within the companies, this R\&D effort would not have been funded to the level he deemed that it needed. Representatives of a raw material supplier noted the growing pressures on availability of R\&D funds within their 
industrial sector generally and their company specifically. This representative indicated the private sector is changing direction with regard to cost sharing. With an increased attention on the short-term "bottom line," justifying participation in R\&D projects is becoming more difficult. An auto industry interviewee indicated that without DOE funding it is questionable whether the company would have pursued the technical issues that will be considered Phase II of these projects.

With regard to collaborative efforts, interviewees acknowledged that new relationships were developed among universities, raw material suppliers, the auto industries, and parts suppliers. One automaker representative commented that the collaborative effort with representatives from other automakers was a benefit of this project because collaborative efforts to solve problems extended beyond the traditional peer group interactions through conferences and professional organizations. The raw material representatives indicated new relationships were established with universities.

On competitiveness of those receiving funding, some participants indicated that their competitiveness would not increase, while others suggested that the companies would not engage in this effort on a commercial basis because it does not fit within their corporate strategy. Beyond the technical issues that will be researched in Phase II, barriers to adoption include cost consideration (aluminum is more expensive than steel), lack of consumer demand for fuel efficient automobiles, and consumer concerns on safety. Moreover, one interviewee noted that evaluators must be aware that the cycle time for the automobile industry (three to five years) and the additional capital investments required by those in the automobile parts industry could push commercialization several more years into the future. Another interviewee felt that the limitations to these processes discovered in Phase I could be overcome and commercialization would occur. He emphasized the long-term nature of research through the learning process. While researchers can anticipate issues in the initialization of a project, in all likelihood different problems arise than anticipated. This is the learning research process.

\subsubsection{Manufacturing of Composite Automotive Structures Project}

The specific objectives of focal project II-high volume-liquid composite molding technology-were to develop and demonstrate rapid manufacturing technology, material performance data, and reliable assembly methods that would produce large and complex composite automotive structures. The project was successful in that Ford is using the P4 technology in its Aston Martin and General Motors is using the P4 technology in its Silverado pickup truck box. Although several complementary projects (see Table 3.1) were not instrumental in the overall success of the composite molding technology, they did increase the level of knowledge. As one interviewee commented, "what worked in the laboratory would not have succeeded in a production environment." However, he went on to comment that the project was valuable for increasing their knowledge. 
All interviewed participants agreed that this project met its objectives. One interviewee noted the significance of the ACC as a collaborative effort as the force behind success. Although the industry had been investigating the use of composites prior to creation of the ACC and PNGV project, none would have participated to this level without DOE funding. Indeed, representatives from the auto sector as well as the raw material suppliers repeatedly said independently that the resources were not available at the level needed for this project to come to fruition. One representative noted that the ACC was specifically formed because no one car maker would have been able to apply the level of resources needed for this type of research. Another commented that his firm might have been engaged in the research, but not to the level of resources committed or the breadth of coverage without DOE funding. The conclusion among interviewees was that, at the very least, the pace from the automakers would have been considerably slower had DOE not invested in this project. Moreover, federal funding was needed to move the composite molding technology from a laboratory scale to full-scale demonstration. Finally, one benefit that was not quantifiable was the increased knowledge level that resulted from this project.

All interviewees noted that collaboration was enhanced and new relationships were developed between the raw material suppliers and the auto industry, as well as just among the three auto makers. One industry representative said that he had not worked with his counterparts prior to this project. There was also involvement by several national laboratories in this project, and those relationships were strengthened.

The respondents were of mixed opinion about whether the research project will result in increased competitiveness for those involved. From a raw material perspective (glass fiber contents), there might be a short-term increase in competitiveness but as the market grows stronger other suppliers will enter the market. In general, representatives of the auto industry feel that the market will increase due to the introduction of composite technology.

On barriers to greater introduction, lack of consumer demand was mentioned along with cost issues. Note that the composite molding technology is cost competitive with steel at a production rate of 50,000 vehicles per year, which would be considered a low production rate for the auto industry.

At the conclusion of each interview conducted under this evaluation project, the interviewees were asked if there were any additional issues they would like to raise. An interesting observation from the interviewees on this $R \& D$ project was the emphasis on long-term evaluation of $R \& D$ projects from several interviewees from the auto industry and raw material suppliers. Since the P4 technology is being used by two of the three U.S. automakers within five years of the DOE project, the emphasis on long-term evaluation is revealing. One representative said that the 
demonstration and commercialization within a five-year period was amazing; this usually does not occur in new technology development. Nonetheless, the representative went on to elaborate that short-term evaluations should not determine the overall success or failure of PNGV as a public policy program. Rather, the representative stressed vehemently that long-term evaluations must prevail. One reason is that the auto industry is conservative, but beyond that, evaluations of technology development is not a short-term endeavor. Another interviewee expressed a similar opinion: that the value of research should be considered as "future oriented." The increased knowledge base should not be overlooked in the evaluation. Speaking more broadly-beyond this R\&D project-the representative said that "while a technology may not be adopted today, it will be considered in future production discussions."

\subsubsection{Qualitative Assessment Summary}

Overall, the qualitative assessments suggest that all three projects yielded significant benefits. As indicated in Table 4.1, all the projects met their technical goals. All yielded new knowledge and helped to improve collaborations. Prospects for commercialization of the technologies across the three R\&D projects involved are mixed as Ford and GM are using the composite molding technology in its manufacturing processes. An additional important finding is that most of the industry participants would not have engaged in these types of projects with the breadth of coverage or with internal financial commitment, either individually or jointly, without federal funding and that federal support sped up the innovation process.

This approach to benefits assessment proved successful. All key project participants were interviewed. The vast majority were gracious with their time. Many sent along supporting documentation. The interviews yielded the information required for solid qualitative assessments. Focusing on interviewing project managers proved satisfactory, as the number of interviews was kept to a minimum and the project managers included people in the interviews to provide supporting information. No major concerns surfaced during this project that question the application of this approach to any other ALM projects. 
Table 4.1. Summary of qualitative assessments

\begin{tabular}{|c|c|c|c|c|c|}
\hline Project & $\begin{array}{c}\text { Met } \\
\text { technical } \\
\text { objectives? }\end{array}$ & $\begin{array}{l}\text { Yielded new } \\
\text { knowledge? }\end{array}$ & $\begin{array}{l}\text { Will technology } \\
\text { be } \\
\text { commercialized? }\end{array}$ & $\begin{array}{l}\text { Would company } \\
\text { have participated } \\
\text { without federal } \\
\text { funding? }\end{array}$ & $\begin{array}{c}\text { Was } \\
\text { collaboration } \\
\text { enhanced? }\end{array}$ \\
\hline $\begin{array}{l}\text { Continuous } \\
\text { cast }\end{array}$ & Yes & Yes & Mixed opinion & No & Yes \\
\hline $\begin{array}{l}\text { Aluminum } \\
\text { forming }\end{array}$ & Yes & Yes & Uncertain & $\begin{array}{l}\text { Mixed opinion. } \\
\text { For those who } \\
\text { would have, not } \\
\text { with as many } \\
\text { resources or at the } \\
\text { speed of } \\
\text { commercialization }\end{array}$ & Yes \\
\hline Composites & Yes & Yes & Yes & $\begin{array}{l}\text { Mixed opinion. } \\
\text { For those who } \\
\text { would have, not } \\
\text { with as many } \\
\text { resources or at the } \\
\text { speed of } \\
\text { commercialization }\end{array}$ & Yes \\
\hline
\end{tabular}

However, two issues did arise that should be addressed in future efforts. First, one person declined to be interviewed for fear of being misquoted. Second, in the background there is the potential for private sector participants not to agree to be interviewed for fear of compromising competitive information. It is suggested that at the beginning of ALM projects DOE inform key participants that they will be interviewed after the project is completed and that they will be allowed to review all notes from the conversations and the evaluation reports.

\subsection{NATIONAL RESEARCH COUNCIL INDICATORS}

As presented in Section 2.2, three National Research Council indicators were chosen for this benefits evaluation: number of publications, outside review panels, and international competitiveness. Information to substantiate these indicators was drawn from interviews, project reports, and other materials. A summary of the indicators for the three projects evaluated appear in Table 4.2.

The number of publications varied over the three projects. Two key elements appear to have influenced publication rates: corporate culture and involvement of academia. For example, 
publications did not arise from the aluminum continuous casting sheet project because, among the private sector collaborators, one interviewee simply said that his firm did not place emphasis on publishing, while another interviewee mentioned that his corporate structure limited the public release of information included in this project. Only one interviewee listed one publication, that of a conference proceeding. Academia was not involved in this project.

Table 4.2. National Research Council indicators

\begin{tabular}{lcccc}
\hline & $\begin{array}{c}\text { Number of } \\
\text { publications } \\
\text { produced. }\end{array}$ & $\begin{array}{c}\text { Does it use } \\
\text { an outside } \\
\text { review } \\
\text { panel? }\end{array}$ & $\begin{array}{c}\text { Does it improve } \\
\text { U.S. } \\
\text { international } \\
\text { Project }\end{array}$ & $\begin{array}{c}\text { Is the United } \\
\text { States leading } \\
\text { in R\&D in this } \\
\text { field? }\end{array}$ \\
\hline Continuous cast & 1 & $\mathrm{~N}$ & $\mathrm{Y}$ & $\mathrm{Y}$ \\
Aluminum forming & 5 & $\mathrm{~N}$ & $\mathrm{Y}$ & Mixed \\
Composites & 23 & $\mathrm{~N}$ & $\mathrm{Y}$ & $\mathrm{N}^{4}$ \\
\hline
\end{tabular}

On the other hand, academia was much involved in the aluminum forming project. As a result, this project yielded a master's thesis and a dissertation produced by two U.S. graduate students. In addition, two conference papers were presented and a technical paper was published, for a total of five publications.

Publishing was extensive in the composites project mainly because of a corporate collaborator who published and presented papers at conferences. When considering only the core research endeavor, six publications emerged before March 2001-our arbitrary cutoff for counting publications. However, one peer-reviewed article is in preparation, and another paper was presented and will be published in conference proceedings during June 2001. When considering the subtasks that increased the knowledge level, a key qualitative assessment of the project, an additional 17 were published.

In general, the number of publications from applied projects will probably be lower than for more basic research projects. Corporate culture is one issue that influences publication. Also one potential issue that did not arise in our interviews is the confidentiality of research results. Under the terms of some cooperative research and development agreement (CRADA) projects, even national laboratory and academic partners may be prohibited from publishing research results for some number of years.

No outside review panels (relevance review as outlined by COSEPUP) were involved in any of

${ }^{4}$ The U.S. automakers are leading in commercialization of the equipment, but not in initial development of the technology. 
the three projects. In one instance, an industrial representative pointed out that he wished there had been more direct interaction with the Department of Energy. None expressed a preference or negative reaction to the notion of having an outside review on individual projects, beyond the annual National Research Council review of all PNGV projects; it simply did not occur.

All the projects helped to improve U.S. international competitiveness although the United States does not lead in each area. The participants in each project were asked: "In your opinion is the United States leading, catching up, or behind in research and development . . .?" The responses across R\&D projects were mixed. In the continuous cast, the U.S. is leading in R\&D.

The participants on the forming project responded that with variable binder loads, the United States is catching up with Europeans in this technology, noting however that the Europeans use the technology with steel rather than aluminum. On warm forming, participants had mixed reactions. Some think the United States is staying even with other countries, while others suggest the United States is leading.

Everyone interviewed agreed that the United States did not have the lead in initial R\&D of the composite molding technology, but U.S. companies have a lead in commercialization. Indeed, P4 technology was developed in Europe and later acquired by Owens Corning. Some auto industrial respondents indicated that the European auto manufacturers are already using P4 technology for commercial applications, while others disagreed on the use by European auto makers. Based on the interviews, the disagreement centers around large scale use of composite molding technology.

The benchmark indicator for quantifying competitiveness identified by all participants, across all projects, was the ultimate commercialization by the auto industry.

The National Research Council indicators suggest that on balance the projects were very applied, which is to be expected given the substantial private sector involvement. That none of the projects had outside review panels may not be an issue because the PNGV program has a higher level review process and because all three projects met their technical goals. However, without outside review, it is harder for a benefits evaluation team to evaluate the quality of the research and the ensuing benefits to the research community. All three projects contributed to improving U.S. international competitiveness in their respective areas. Expecting a single project to propel the United States into the lead, however, proved too much to expect.

Overall, the National Research Council indicators provide useful information for a benefits assessment. The information was easily collected. There are no obvious barriers to applying this method to other ALM projects. Future efforts, however, might consider an expanded list of indicators, which includes numbers of patents, R\&D 100 and other awards, copyrights, software products, and working prototypes developed. 


\subsection{BENEFIT-COST ANALYSIS}

As outlined in Section 2.2, the benefit-cost analysis approach has two monetary components. The first component, covered in Sections 4.3.1 through 4.3.5, pertains to the benefits derived from the commercialization of the technologies and a benefit-cost ratio is calculated. The higher the market penetration of new vehicles that benefit from the projects (e.g., vehicles that have higher amounts of sheet aluminum or aluminum parts produced by warm forming processes), the greater the benefits that can be attributed to the projects. The second monetary calculation relates to the counterfactual analysis. These components are covered in Section 4.3.6. A summary of the benefit-cost approach is found in Section 4.3.7.

\subsubsection{Market Penetration}

The market penetration component of the benefit-cost approach itself has three components. The first component, addressed in Section 4.3.2, addresses the potential market penetration of new vehicles that contain materials and/or parts that can be directly attributed to the projects. For this project, market penetration rates are forecast out to the year 2025. The second component addresses benefits gained as the new vehicles are adopted in the marketplace. As laid out in Section 4.3.3, three categories of benefits are assessed: energy, environmental, and production cost reduction. The third component, described in Section 4.3.4, combines the results of the market penetration forecast and the benefits list into three benefit scenarios, where benefits are projected out to the year 2025 and discounted to net present value terms.

\subsubsection{Market Forecasts}

The adoption of new technologies by the three U.S. automakers in future years, both assuming government funding and no government funding, is estimated by using a widely accepted logit model of technology diffusion, adapted by Edwin Mansfield (Mansfield 1995). This model was originally used by Griliches in the late 1950s to describe market penetration and technology diffusion and has been used by other researchers conducting evaluations on the benefit of federal R\&D projects (Chapman, 1999). The Mansfield model estimates the proportion of potential users $P$ who have adopted the new technology by time $t$ as follows:

$$
P(t)=\left[1+e^{(a-b t)}\right]^{-1}
$$

where $a$ and $b$ are the location and shape parameters, respectively. The ratio of $a$ to $b$ specifies the length of time it takes for $P(t)$ to reach 50 percent of its "designated" potential market. 
The availability of low-cost aluminum sheets will help to create a new aluminum-intensive vehicle (AIV) market in North America. An AIV has both an aluminum-intensive body and aluminum-intensive closures. A recent comparison of aluminum and steel body structures by Ducker Research Company indicates that, with continuous cast coated aluminum sheets at $\$ 1.05 / \mathrm{lb}$, aluminum body structures will cost about 1.6 times more than comparable steel structures (Schultz, 2001a). Even a lower material cost for aluminum will not offset its significantly higher stamping and assembly costs. The Ducker study predicts that, with the aluminum sheet at $\$ 1.05 / \mathrm{lb}$, the number of North American aluminum auto bodies with aluminum closures will increase from 43,000 in 2005 to 260,000 vehicles by the year 2009, the last year addressed in the study. To forecast through the year 2025, this analysis uses the Ducker study's estimates and then assumes growth in aluminum will occur per Mansfield's technology diffusion model and will reach a market share of 25 percent of the total mid-size passenger car and sport utility vehicle market by 2024 . Because the cost-effectiveness of aluminum structures remains an issue, it is very unlikely that the share of the AIV market will be more than 25 percent of the passenger cars and sport utility vehicle segments, which each occupy about 35 percent of the light-duty vehicles market. In addition, competing developments, such as ultralight steel autobody (ULSAB) and ultralight steel autoclosures (ULSAC), have made significant and cost-effective lightweighting improvements. The forecasts of new light-duty vehicle sales and the share of passenger cars are based on the Energy Information Administration (EIA) (2001 Reference Case Energy Outlook) for the period 2005-2020, which were further extrapolated for the years 2021 to 2025 . The quantity of aluminum per vehicle for body structure and closure panel is assumed to be $313 \mathrm{lbs}$ and $117 \mathrm{lbs}$, respectively.

The North American market for aluminum closure panels on nonaluminum body vehicles will also increase as a result of a low-cost aluminum sheet. To date, the use of aluminum sheets in the North American automotive market has been limited to a small number of hoods and decklids. The recent Ducker study also predicts that the use of aluminum sheet in this sector will continue to grow from 50 million lbs in 1999 to 120 million lbs of sheet by 2009, capturing almost $30 \%$ of hood applications in the light-duty vehicles market by 2009 (Schultz 2001a). It is assumed here that the penetration of a low-cost aluminum sheet will occur at the same rate as AIVs, but the additional number of vehicles containing aluminum closure panels will be half that assumed for AIVs. Development of low-cost aluminum sheet has been limited to 5000 -series aluminum and so the above given forecasts have been adjusted accordingly. This analysis assumes that the content of 5000-series aluminum in closure panels (mainly used for inner panels) of steel vehicles is 67 percent through 2015, and 50 percent thereafter. Similar adjustments were also made for aluminum-intensive vehicles as discussed above.

Figure 4.1 shows the projected amount of 5000-series aluminum sheet required and the number of light-duty vehicles produced that will use low-cost aluminum sheet during 2005-2025. Assuming initial market penetration date of 2005 as shown by the solid lines in this figure, it is estimated that the number of vehicles will increase from 75,000 in 2005 to 2.4 million vehicles (i.e., about 15 percent of total light-duty vehicles market) in 2025. The corresponding increase in 
the amount of 5000-series aluminum sheet will be 21 and 650 million lbs, respectively. Note that North American aluminum auto body sheet shipments in 1999 were about 50 million lbs (i.e., 2 percent of primary aluminum shipments), mostly as non-AIV closures such as hoods, truck lids, and liftgates (Schultz, 1999). Shipments are already projected to increase to 225 million lbs by 2009 due to lower sheet cost (Schultz, 1999), compared to estimated low-cost 5000-series sheet increase in demand in 2009 by 108 million lbs.

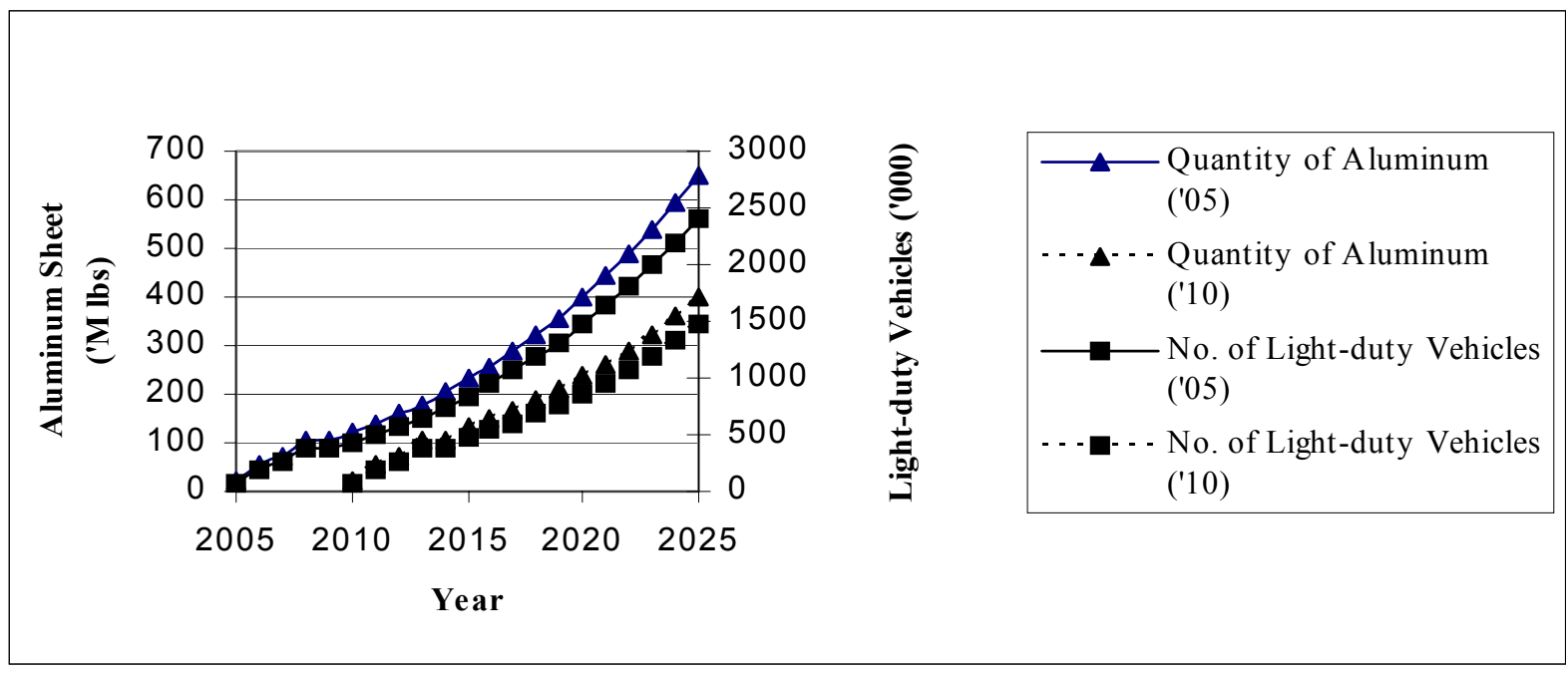

Fig. 4.1 Forecast of Effects of Low Cost 5000-series Aluminum Sheet

To assess the role of federal R\&D in advancing technology commercialization, we asked each participant: "In the absence of DOE funding, how many additional person years of research effort would it have taken . . . to achieve the same level of manufacturing efficiency ...?" Based on the responses from those involved with the continuous cast project, it is assumed here that the government R\&D spending would help by five years in the early introduction of this technology into the marketplace. The penetration of this technology would begin in 2010 in the absence of government R\&D spending, by assuming the shifting of only the penetration curve of this technology as discussed above by five years, while keeping the EIA annual market forecasts of light-duty vehicle sales and the share of passenger cars as before. These new penetration curves of quantity of aluminum and the number of light-duty vehicles are shown as dotted lines in Figure 4.1. The area between the solid and dotted lines provides the estimated early market penetration benefits of aluminum vehicles due to low cost aluminum sheet, which is estimated to about a little more than half of the total market potential as shown in this figure.

\section{Advanced Forming Technologies for Aluminum Market Forecast}

A procedure similar to the one discussed above is used to estimate increases in aluminum use that would result from the availability of successful, new approaches to forming aluminum parts. First, we calculated the combined impacts of low-cost aluminum sheet and new aluminum forming approaches, see Figure 4.2. Then, the difference between the combined effect and the effect of low-cost aluminum sheet alone yields the effect of forming technologies. Assuming a 
"best case" scenario in which the cost of aluminum body structures is equal to or less than 125 percent of the cost of steel structures, the Ducker study projected the North American aluminum auto body market with closures to increase from 43 million lbs in 2005 to 567 million lbs by 2009 (Schultz 2001a). These forecasts are 50 percent to 150 percent higher than those estimated using a $\$ 1 / \mathrm{lb}$ assumption for aluminum sheet and used for the low-cost aluminum sheet project here. It is likely that the alternative forming approaches will not only reduce the stamping cost but also lower scrappage rates, leading to a significantly lower material cost. For the initial period, i.e., 2005-2009, the forecasts of the increased aluminum use are based on the Ducker estimates of aluminum auto bodies with closures for the best-case scenario. Forecasts of the remaining years of the analysis period are estimated using Mansfield's technology diffusion model which was calibrated to: (i) the 2009 "best case" scenario estimate of the Ducker study and (ii) achieve a market share of 35 percent of total mid-size passenger cars and sport utility vehicles in 20 years. This market share is 10 percent higher than that assumed for the low-cost aluminum sheet forecast. Other assumptions, e.g., regarding forecasts of light-duty vehicle sales and aluminum content per vehicle, are the same here as they were for the low-cost aluminum sheet forecasts. Since the new forming approaches have been demonstrated only in 5000-series aluminum applications (e..g, Dodge Neon inner door panel), estimated impacts here are limited to that category of aluminum. To capture the effects of forming technologies on nonaluminumbody vehicles that have aluminum closures, an additional 50 percent of the estimated number of aluminum-intensive vehicles are considered.

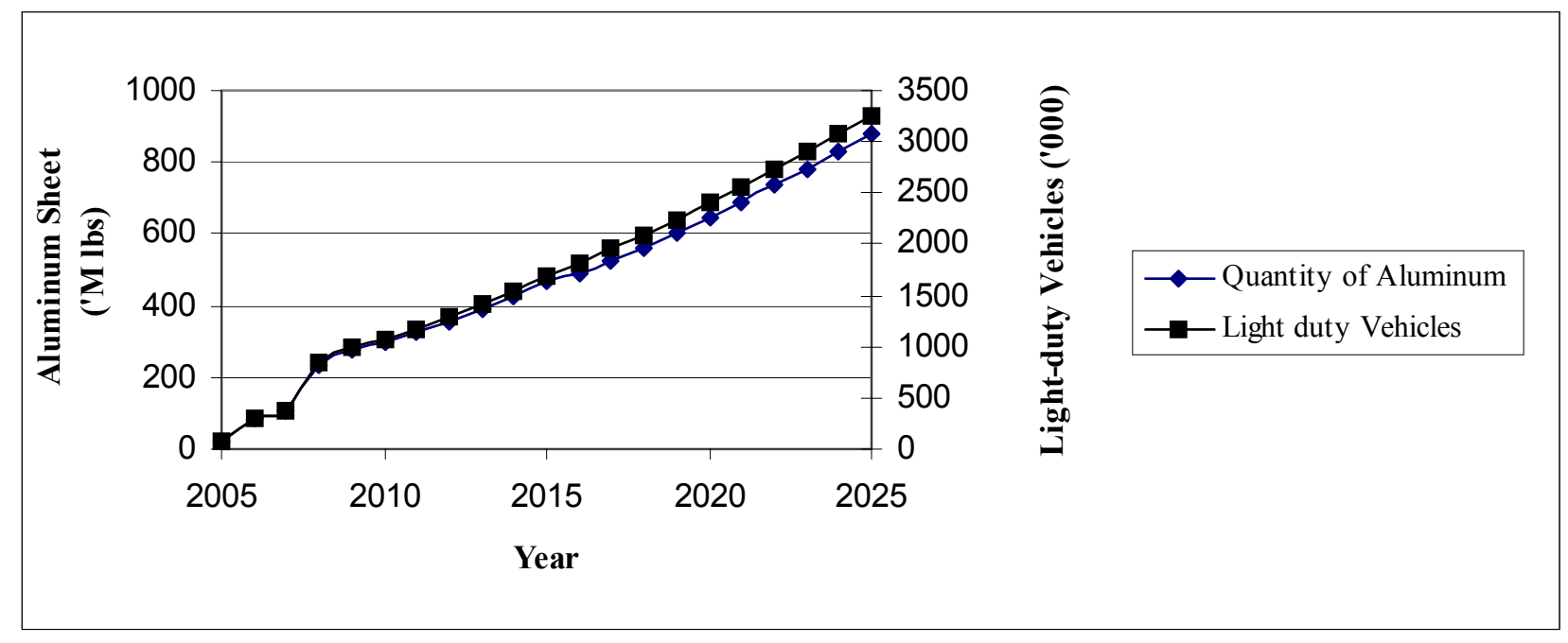

Fig. 4.2 Low Cost Aluminum Sheet and Advanced Forming Forecast 
It is assumed here that new approaches to forming aluminum parts will not become effective until 2008, about 3 to 4 years after the successful completion of the Phase 2 of this project. Without the government R\&D funding, the market impacts of advanced forming technologies will not begin for another five years (same as was assumed in the case of low cost aluminum sheet), until 2013. To determine the market penetration of advanced forming technologies based on the two different years of the start date of market forecasts, the forecasts of the combined effect (Figure 4.2) and the effect of low-cost aluminum sheet alone (Figure 4.1) were moved ahead by the specific number of years, while maintaining the EIA annual forecasts of new lightduty vehicle sales and the share of passenger cars same as before. The difference in the penetration rate between the two cases yields the effect of forming technologies, as shown in Figure 4.3, for both cases of different initial start date of penetration of this technology. The benefit of government R\&D support of this technology is estimated as the area between the solid and dotted lines as shown in this figure, which is estimated to be one-third of the total market potential.

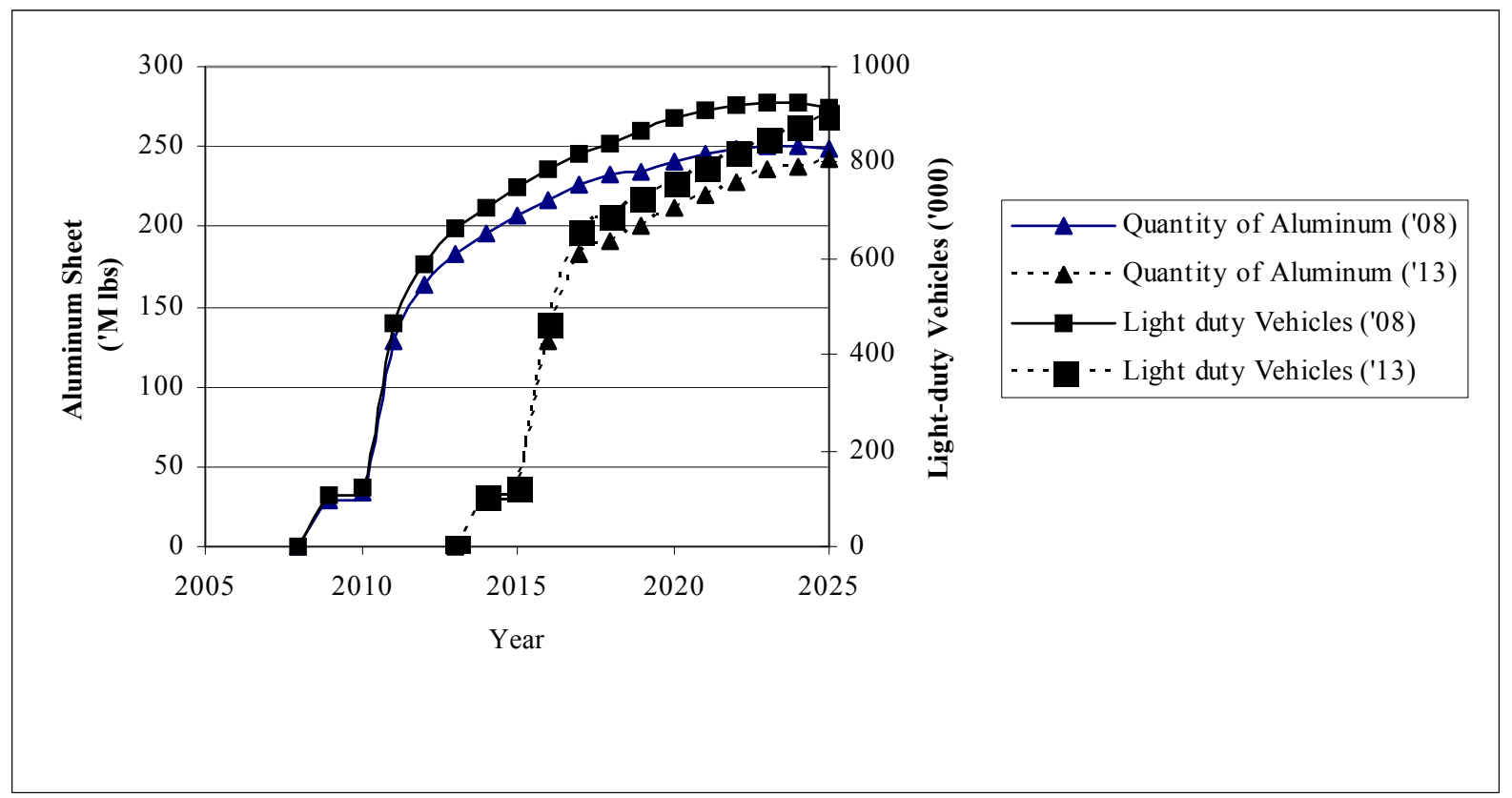

Fig. 4.3 Forecast of Effects of New Automotive Aluminum Forming Technologies

A recent Ducker study indicates that at a high annual production volume, the difference between stamped steel and stamped aluminum automotive assemblies is $\$ 810$, where variable costs such as material and processing contribute 45 percent and 24 percent, respectively, of this total difference (Schultz 2001b). It is thereby anticipated that the impact of low-cost aluminum sheets will be greater than the impact of new approaches to forming aluminum parts, and the combined impacts will be considerably greater than either of them alone. As shown in Figures 4.1 and 4.3, aluminum use will increase from 21 million lbs in 2005 to 650 million lbs in 2025 in the former case, compared to about 250 million lbs in 2025 in the latter case with the initial market 
penetration date as 2008. Under the most favorable circumstance (i.e., low-cost aluminum sheet and new approaches to forming aluminum parts), the projected number of additional vehicles containing aluminum sheet will grow to 3.3 million vehicles (about 21 percent of total light-duty vehicles market) by 2025 . Note that the number of aluminum vehicles increase to 917,000 by 2025 in the case of new approaches to forming aluminum parts, compared to 2.4 million vehicles in the case of low-cost aluminum sheets with the initial market penetration date of 2005 as shown before in Figure 4.1.

\section{Manufacturing of Composite Automotive Structures Market Forecast}

An initial estimate by the developer of the composite molding technology indicates that the annual volume of composite pickup truck beds could grow to more than 220,000 units or 50,000 metric tons by 2004 (AMM 1999, Composites Technology 2000). Using the EIA 2001 referencecase forecasts of the number of pickup trucks in North America, the parameters (i.e., $a$ and $b$ ) of the technology diffusion model were calibrated to the developer's 2004 forecasts and limit the share of this technology in the open cargo area pickup truck market to 50 percent or less by 2025. This technology is assumed to maintain the current composites use in automotive applications. Composites in automotive applications have been limited to low production volumes because composites offer shortened lead times and lower investment costs relative to conventional steel production. A recent cost analysis of this technology for a truck box made of composites has similarly found that the technology is competitive to steel at annual volumes in the 50,000 to 100,000 range (Denton et al., 2000). It is estimated that the total market for this technology in open cargo areas of pickup trucks will increase from 239,000 in 2005 to about 1.1 million trucks by 2025 . Note that of the 2.9 million pickup trucks sold by U.S. manufacturers in 1999-where Ford and General Motors have market shares roughly equal to each other and higher than DaimlerChrysler's share-there were about 0.5 million Silverado trucks (WC, 2000). To translate this forecast of units into a forecast of production volume for glass-reinforced composites, the analysis assumes $250 \mathrm{lbs}$ of composites per truck and the estimated pickup truck market size as discussed above. This forecast is presented in Figure 4.4.

The other potential market for this composites technology is in structural automotive applications. Ford is using this technology for three large, semi-structural components (i.e., upper cargo deck and right/left hand bodysides) on its limited number of Aston Martin Vanquish vehicles (Chavka, Dahl and Kleven, 2001). Also, Delphi Automotive Systems is considering this technology for automotive bumpers. Hence, the penetration of this technology in new car sales could be substantial. The number of vehicles using this technology was estimated using the EIA 2001 reference-case forecast of new car sales and the penetration rate estimated by Mansfield's technology diffusion model (Mansfield, 1995). The parameters of the diffusion model were calibrated in a way that use of this technology slowly climbs to the preliminary industry estimate of the 2005 market and limits the total penetration rate of this technology in structural composite automotive applications to not more than 5 percent of new cars by 2015 and 10 percent by 2025 , the end of the forecast period. It is unlikely that the maximum penetration rate could be any higher than the assumed 10 percent because of competition from advancements in steel and aluminum and because this technology has been found to be cost-effective only in low-to- 
medium volume applications as noted above. The forecasts for glass reinforced composites using this technology are based on the average quantity of material used in the body-in-white (BIW) structure (i.e., $370 \mathrm{lbs}$ ), despite the likelihood that initial application will occur only in select BIW structural components, as in the case of Ford and Delphi today. Since the number of vehicles using composites in structural applications is likely to be higher than is assumed here, the higher amount of material use per vehicle assumed here is to capture those impacts.

The market forecasts for this glass-reinforced automotive composites technology for open cargo truck boxes and structural passenger car applications are shown in Figure 4.4. The combined

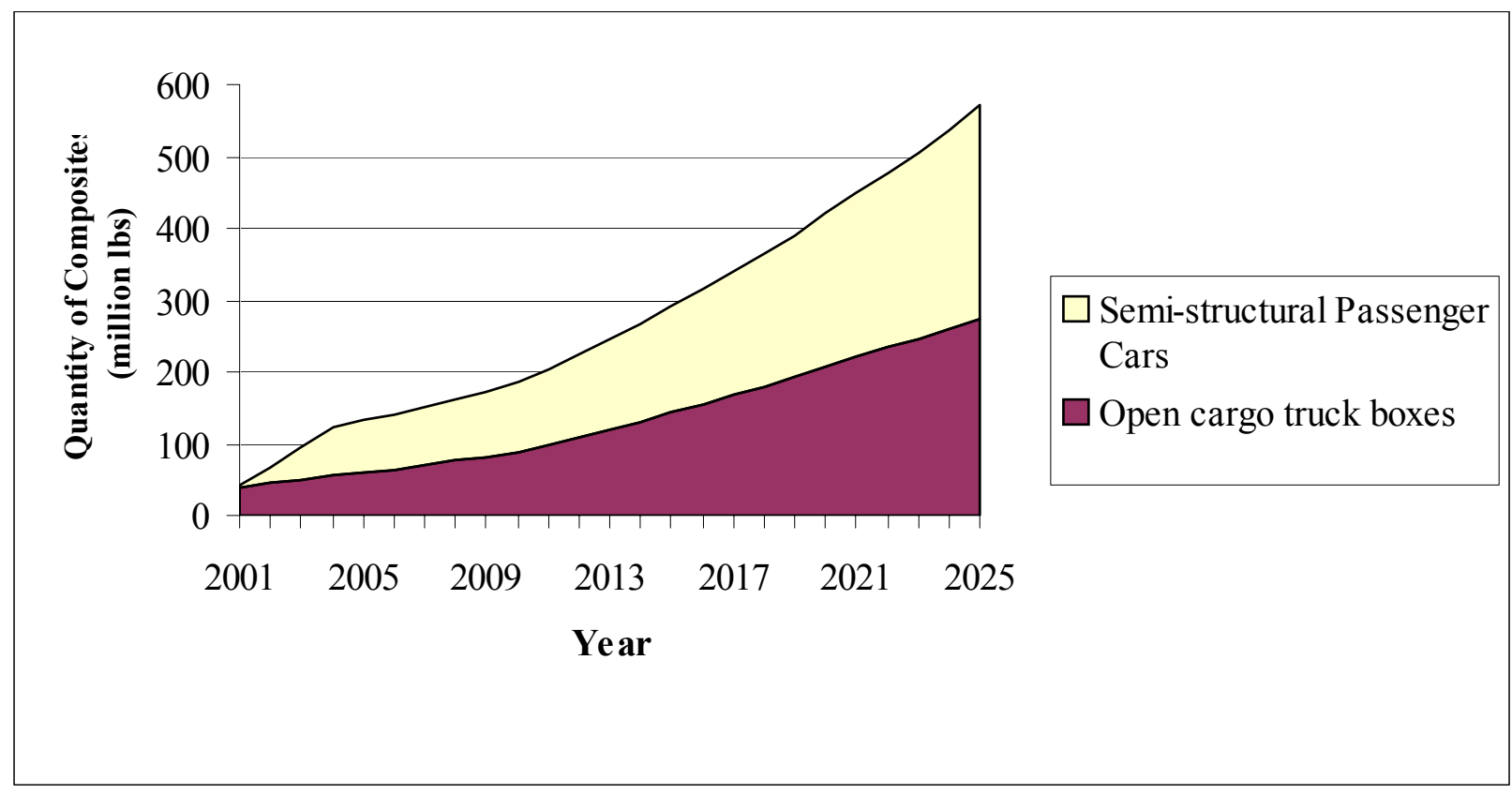

Fig 4.4 Manufacturing of Automotive Composite Structures Forecast

market for this technology will grow from 40 million lbs in 2001 to about 570 million lbs by 2025. The structural automotive component application of this technology is assumed to grow at a significantly higher rate during the latter years of the forecast period, increasing from 149 million lbs in 2015 to 296 million lbs by 2025 . These forecasts represent a significant growth in structural applications of composites, which today are limited mainly to liquid molded (resin transfer molding (RTM)/SRIM) composite materials. Of the 318 million lbs of automotive composites manufactured in 1999, there were about 353 thousand lbs of RTM components for light-duty vehicles applications (ACA, 2000). As a comparison, according to the Automotive Composites Alliance (ACA), automakers will use 350 million lbs of reinforced thermoset composites in 2001, increasing to 467 million lbs by 2004 (Composites Technology, 2001).

As before, benefit estimates of composite automotive structures were based on the estimated increased market size due to early introduction of this technology into the marketplace. The introduction of this technology is assumed to be delayed by five years (i.e., 2006 instead of 
2001) in the absence of government R\&D funding, as before. Figure 4.5 shows the market forecasts of two starting dates, i.e., 2001 and 2006, where the latter forecasts were based only on shifting the former ones as discussed above in Figure 4.4, by five years. The area between the

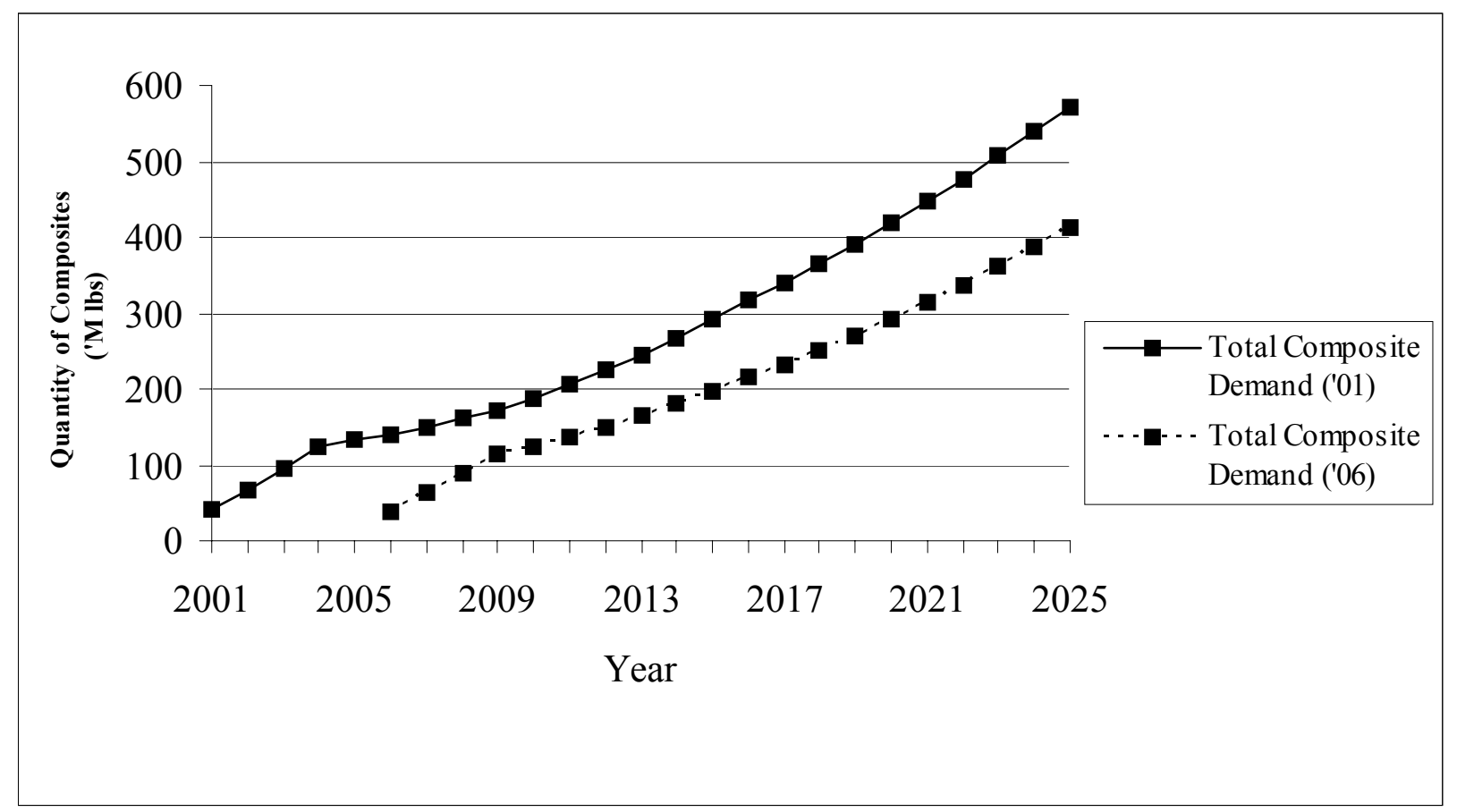

Fig. 4.5 Alternative Forecasts of Automotive Composite Structures

solid and dotted lines in this figure provides the benefits of early entry into the market due to government R\&D funding, which appears to be a little more than $1 / 3$ of the total market size over the forecast period considered here.

\subsubsection{Energy, Environmental, and Production Efficiency Benefits}

This section addresses the benefits attributable to the new vehicles that are forecast to be on the road based on the analysis presented above. First to be considered are energy and environmental benefits. Energy benefits will accrue because the new vehicles will be lighter than today's vehicles. Reduced weight leads to reduced energy consumption, holding constant vehicle miles driven, driving styles, and road and weather conditions. Environmental benefits will accrue during the use of these vehicles because for every gallon of gasoline saved there will be corresponding reductions in air pollution emissions. In this analysis, specific benefits assessed are gallons of gasoline saved and reductions in $\mathrm{CO}_{2}$, carbon monoxide (CO), particulate matter $\left(\mathrm{PM}_{10}\right)$, nitrogen oxides $\left(\mathrm{NO}_{\mathrm{X}}\right)$, and sulfur oxide $\left(\mathrm{SO}_{\mathrm{X}}\right)$ emissions.

The above reductions of environmental burdens are associated with the use phase of the automobile. There are potentially other environmental benefits and costs associated with using new lightweight materials in vehicles. To gain insights into these other benefits, it is useful to 
adopt a life cycle view of automobiles and their components. Within the life-cycle framework, our analysis will consider the extraction of raw materials from the earth, the processing of raw materials into refined forms, the manufacture of automobile parts and components from processed materials, and the recycling, reuse or disposal of automobile parts and components of end-of-life vehicles. Environmental emissions and issues are associated with each of these phases, in addition to the vehicle-use phase addressed in the previous paragraph. Because it can be an enormous undertaking to track every material at every stage in the life cycle, this research focuses on only four of the five phases: extraction, materials processing, manufacturing, and use. These phases represent most of the environmental emissions associated with the automobile industry.

Thus, the life cycle assessment task is centered around examining the environmental consequences of replacing steel components in vehicles with aluminum sheet, aluminum parts produced by variable binder controls or warm forming, and glass composites produced by the composite molding technology. Staff at the University of Tennessee's Center for Clean Products and Clean Technology provided estimates for the amounts of energy used and environmental pollutants emitted in producing a pound of steel, aluminum, and glass composite material. These numbers had been previously developed during other life cycle assessment projects at the Center, including two projects supported by the DOE and managed by ORNL related to the PNGV program. These numbers were translated into savings in energy use and environmental emissions per pound of new material used in the vehicles for an aggregate extraction, processing, and manufacturing stage, and for the use stage. These translated numbers are shown in Table 4.3.

Table 4.3. Energy and environmental savings per pound of material used

\begin{tabular}{lcccc}
\hline Project Area & \multicolumn{2}{c}{ Aluminum } & \multicolumn{2}{c}{ Glass Composites } \\
\cline { 2 - 5 } & $\begin{array}{l}\text { Extraction, } \\
\text { processing, } \\
\text { manufacturing }\end{array}$ & Vehicle use & $\begin{array}{c}\text { Extraction, } \\
\text { processing, } \\
\text { manufacturing }\end{array}$ & Vehicle use \\
\hline Energy (mmBtu) & -0.0974 & 0.1569 & -0.0053 & 0.0857 \\
$\mathbf{C O}_{\mathbf{2}}(\mathbf{l b s})$ & -9.3978 & 28.1342 & 1.2570 & 15.3684 \\
$\mathbf{C O}(\mathbf{l b s})$ & -0.0012 & 0.1093 & -0.0056 & 0.0445 \\
$\mathbf{P M}_{\mathbf{1 0}}(\mathbf{l b s})$ & -0.0178 & 0.0049 & 0.0279 & 0.0026 \\
$\mathbf{N O}_{\mathbf{X}}(\mathbf{l b s})$ & -0.0414 & 0.0210 & -0.0143 & 0.0114 \\
$\mathbf{S O}_{\mathbf{x}}(\mathbf{l b s})$ & -0.0466 & 0.0222 & -0.0145 & 0.0122 \\
\hline
\end{tabular}

Table 4.3 illustrates that the energy and environmental costs and benefits associated with new lightweight vehicles, which employ more aluminum and/or glass composites, are complex. Generally, in the use phase, there are appreciable energy and environmental emission savings. 
However, with respect to the extraction, processing, and manufacturing phases, the picture is different. Aluminum in particular requires more energy to process than steel. The extraction of the raw materials needed for aluminum is also more energy intensive than for the components of steel. Because of the increase in energy needs, more environmental emissions are associated with aluminum than with steel. On the other hand, emissions are generally lower for these phases for glass composites.

In addition to understanding the magnitude of the energy and environmental impacts, we need to determine the monetary value of the impacts. In other words, what is the value of reducing fuel consumption by a gallon? Estimating these monetary values is a difficult and controversial exercise, one of the main criticisms of the use of benefit-cost analysis in the environmental field. Nevertheless, many attempts have been made to estimate these values. Riggert et al. (1999) have done a thorough job of reviewing the literature to distill the ranges in benefit estimates related to environmental emissions. EIA publishes price forecasts for energy products. Using these sources, we developed three value scenarios, indicated in Table 4.4. For example, the range of value estimates for saving a gallon of gasoline range from a low of $\$ 1.33$ per gallon to a high of $\$ 2.00$ per gallon. Gasoline savings are associated with the vehicle use phase whereas oil savings are associated with the extraction, processing, and manufacturing stage.

Table 4.4. Energy and environmental emission values scenarios

\begin{tabular}{rccc}
\hline & Base values case & Moderate values case & High values case \\
\hline Oil (\$/barrel) & 25 & 30 & 40 \\
Gas (\$/gallon) & 1.33 & 1.63 & 2.00 \\
$\mathbf{C O}$ (\$/ton) & 7 & 27 & 55 \\
$\mathbf{C O}$ (\$/ton) & 920 & 1000 & 1086 \\
$\mathbf{P M}_{\mathbf{1 0}}$ (\$/ton) & 40 & 1000 & 9953 \\
$\mathbf{N O}_{\mathbf{x}}$ (\$/ton) & 44 & 600 & 8143 \\
$\mathbf{S O}_{\mathbf{x}}$ (\$/ton) & 110 & 200 & 2030 \\
\hline
\end{tabular}

As Table 4.4 suggests, the range in values is quite large for several of the environmental emissions. The base and high values cases represent the published ranges. The moderate case represents values that are more realistic than the low and high values cases. 


\subsubsection{Market Penetration Benefit Estimates}

Table 4.5 presents the energy and environmental net present value benefits attributable to the projects, given the market penetration forecasts out to the year 2025, the values presented above, and a 3.2 percent discount rate, which is the current rate recommended by the Office of Management and Budget for use in program evaluation. Benefits are presented for the three cases described above. As expected, the energy and environmental benefits for the extraction, processing, and manufacturing phases are negative in several instances. However, the use-phase benefits outweighed these negative benefits in every case, causing net positive benefits. Energy benefits are significantly higher than environmental benefits, although there still exists quite a controversy over the value of the impacts in the latter case. Although significant weight reduction and a higher market penetration potential of aluminum exist in the case of the continuous cast aluminum sheet, the benefits are not the most under this case due to the energy intensive manufacturing process. The estimated benefits will depend on the forecast period under consideration, which is quite long in our case.

Table 4.5. Energy and environmental benefit results (\$ millions)

\begin{tabular}{|c|c|c|c|}
\hline Projects & Energy & Environment & Total \\
\hline \multicolumn{4}{|c|}{ BASE CASE } \\
\hline Continuous cast & $\$ 1072$ & $\$ 87$ & $\$ 1159$ \\
\hline Aluminum forming & $\$ 816$ & $\$ 67$ & $\$ 883$ \\
\hline Composites & $\$ 1212$ & $\$ 92$ & $\$ 1304$ \\
\hline \multicolumn{4}{|c|}{ MODERATE VALUES CASE } \\
\hline Continuous cast & $\$ 1335$ & $\$ 194$ & $\$ 1529$ \\
\hline Aluminum forming & $\$ 1010$ & $\$ 172$ & $\$ 1182$ \\
\hline Composites & $\$ 1486$ & $\$ 329$ & $\$ 1815$ \\
\hline \multicolumn{4}{|c|}{ HIGH VALUES CASE } \\
\hline Continuous cast & $\$ 1531$ & $\$ 56$ & $\$ 1586$ \\
\hline Aluminum forming & $\$ 1187$ & $\$ 190$ & $\$ 1377$ \\
\hline Composites & $\$ 1817$ & $\$ 794$ & $\$ 2612$ \\
\hline
\end{tabular}

To complete the market benefits analysis, Table 4.6 presents the cost reduction benefits associated with using the new continuous cast technology over the older multi-step technology. The cost reduction savings per pound of aluminum produced are based on the estimates obtained 
Table 4.6. Cost reductions associated with continuous casting of aluminum: AIV only (\$ millions)

\begin{tabular}{|l|c|c|c|}
\hline Cost Reduction (\$ per lb of aluminum produced) & 0.06 & 0.08 & 0.11 \\
\hline & $\$ 198$ & $\$ 264$ & $\$ 363$ \\
\hline
\end{tabular}

as a part of the project (Reynolds Metals Company, 1999). There are no readily apparent cost reductions associated with the forming or composite projects.

\subsubsection{Benefit-Cost Ratios}

Table 4.7 contains benefit-cost ratios for the projects. These were calculated by adding together the monetized energy, environmental, and cost reduction benefits and dividing by the project costs. Note that the benefit-cost ratios were calculated by taking into consideration the environmental benefits, which remain quite controversial in the literature today. The project costs indicated in Table 4.7 represent both DOE and private sector contributions to the projects. In every instance, the benefit-cost ratios are substantial. These ratios are higher than those reported by Link and Scott (1998) for five ATP projects, which range from 4 to 85, and Martin et al. (2000) for a project entitled "Standard Reference Materials for Sulfur in Fossil Fuels", which was 113. However, these ratios appear to be consistent with those reported by Chapman and Fuller (1996) for two NIST programs and by Yuracko, Tonn, and Morris (1999) for several pollution projects funded by DOE at the Oak Ridge Reservation. Note that life cycle impacts covering quite a long forecast period of 25 years maximum was considered for the three projects in this study.

Table 4.7. Benefit-cost ratios

\begin{tabular}{lcccc}
\hline Project & $\begin{array}{c}\text { Project Cost } \\
\text { (\$ millions) }\end{array}$ & $\begin{array}{c}\text { B-C Ratio* } \\
\text { Base Case }\end{array}$ & $\begin{array}{c}\text { B-C Ratio* } \\
\text { Moderate Case }\end{array}$ & $\begin{array}{c}\text { B-C Ratio* } \\
\text { High Case }\end{array}$ \\
\hline Continuous cast & 2.790 & $455(486)$ & $573(643)$ & $679(699)$ \\
Aluminum forming & 5.088 & $160(174)$ & $199(232)$ & $233(271)$ \\
Composites & 7.746 & $156(168)$ & $192(234)$ & $235(337)$ \\
\hline
\end{tabular}

*Numbers inside parenthesis indicate B-C ratios by taking environmental benefits also into consideration. 


\subsubsection{Counterfactual Analysis}

These benefits probe what might have happened had DOE not provided funds for the project. It measures how many person-years the firms would have had to support solely with their own funding in place of DOE funding as shown in Table 4.8. In each R\&D project, we asked participants: "In the absence of DOE funding, how many additional person-years of research effort would it have taken your firm to achieve the same level of manufacturing efficiency ...?" The cost savings indicated for each project in this table are based on the summation of savings estimates as provided by each project partners with varying person-year cost rate and cost type. In the continuous cast project, participants indicated it would have taken three to four personyears, with a person-year valued at between $\$ 100,000$ and $\$ 200,000$. One company said two additional staff would have been needed per year, while another interviewee replied that three additional staff would have been needed per year.

Table 4.8. Counterfactual benefit estimates

\begin{tabular}{lccc}
\hline & Continuous cast & Aluminum forming & Composites \\
\hline $\begin{array}{l}\text { Time savings } \\
\text { (Person-years) }\end{array}$ & 18 & 37 & 70 \\
Cost savings & & & \\
\hline
\end{tabular}

With respect to the aluminum forming project, the responses varied on the amount of effort it would have taken firms to achieve the same level of research knowledge from Phase I of these tasks. The responses ranged from one year, because of familiarity with some of the technologies, to four years. One interviewee said it would have taken eight full-time staff a total of four years each to achieve the same level of manufacturing efficiency. Estimates of cost savings by having access to DOE funding totaled a "conservative" estimate of about $\$ 600,000$ for the aluminum forming project alone. Several interviewees had difficulty assigning a quantitative number in response to this question. All understood the clarity of the question and its significance in the analysis. Yet they replied that attaching a dollar value was difficult.

With respect to the composites project, one firm said that it would have taken 12 additional staff members 5 years, at $\$ 200,000$ per person. Another said that it would have taken his firm an additional five years, although he could not quantify additional staff members or their cost. Another interviewee said he felt the funding level of DOE and industry cost-sharing for the P4 main task (approximately $\$ 4.3$ million) was a realistic estimate of the cost and time savings for this project from his perspective. 


\subsubsection{Benefit-Cost Approach Summary}

Setting the benefit-cost ratios aside for the moment, the benefit-cost approach required detailed assessments of the potential market penetration of new vehicles and the associated energy, environmental, and cost reduction benefits. These tasks helped to identify the range of benefits, a useful outcome in its own right. Adding values to the benefits helps to indicate the magnitude of the benefits IF the new technologies are commercialized. While benefit-cost analysis is time consuming, there were no technical barriers to its implementation in this context.

With regard to the benefit-cost ratios, it must be noted that there are several qualifications to the ratios presented above. The market penetration dates and rates of the technologies are quite uncertain; uncertainties associated with aluminum technologies being much higher than the uncertainties associated with the composite technology. Also, there are significant uncertainties related to the values assigned to the reduction of air pollutants and to saving oil and gas. This research only dealt with these uncertainties in a small way, by incorporating three different valuation scenarios. Future research in this area should consider more sophisticated benefit-cost techniques that explicitly address uncertainty so that expected benefit-cost ratios can be calculated. One such method is options pricing analysis (Angelis, 2000).

Additional research is needed on valuing reductions in pollutants. Some values in the literature are based on forecasted values for emission permits (e.g., the value of a permit to emit one ton of carbon into the atmosphere) whereas other values focus on valuing the reduction in human deaths and health effects due to reductions in emissions. Both types of estimates are included in this analysis. Whether this is appropriate needs to be determined and if not, appropriate valuation approaches need to be adopted.

Next, the cost estimates do not include the investment costs to be borne by the automobile industry or suppliers to implement the technologies. These costs could be significant, as they not only would include new capital equipment but could also include costs associated with redesigning manufacturing processes and re-training employees. Including these costs would lower the benefit-cost ratios.

Lastly, the benefits are only forecasted to the year 2025 . One can easily imagine that benefits could be accrued for many years beyond the year 2025, which would mean that the benefits and ratios are understated. On the other hand, there is the possibility that these technologies could be replaced by even better materials and/or technologies several years hence.

With regard to the counterfactual monetary values, several participants did not respond with a dollar value for person year saved through access to federal R\&D. Nevertheless, they all could determine how many person-years time savings occurred through funding available through DOE. 


\subsection{TRACKING FUTURE BENEFITS}

Overall, the three approaches for assessing benefits provided useful information. A question still remains, however, about tracking future benefits associated with the projects. The issue is that it may be premature to judge the benefits of just completed or nearly completed projects that could have long-term benefits. Here are three suggestions that are appropriate to this context:

- Publications tracking. Journal papers and technical reports in process can be tracked to completion. To gauge the value of these resources to the R\&D community, a citation search engine, such as the Web of Science, can be used periodically for this purpose.

- Technology tracking. Every several years, evaluators can check with the private sector producers of materials and manufacturers of vehicles to ascertain whether the technology was commercialized, and if so, how many vehicles are in use that benefit from the technology. Updated market penetration forecasts should be prepared.

- Qualitative innovation tracking. In many instances, new technologies do not pan out as intended but yield huge benefits for other applications or lead to newer and better innovations. In-depth case studies can be conducted to document the evolution of applications and new technologies. 


\section{CONCLUSIONS}

This research applied three approaches to assess the benefits attributable to three ALM projects. The first conclusion is that each of the three approaches appears suitable for this purpose. Interviews and assessment of project materials proved quite sufficient for the qualitative assessment and National Research Council indicators. Additional information was needed for the benefit-cost analysis, but most of this information was readily available in the literature. There were no significant barriers to application of these approaches and no anticipated unsurmountable barriers to using these approaches to assess the benefits of other ALM projects.

The second conclusion is that all three approaches are needed to present a comprehensive benefits assessment. The qualitative assessment is useful for assessing project-level, relatively short-term, accomplishments. The National Research Council indicators focus on the quality of the research, again within the short term. Benefit-cost analysis addresses commercialization and associated societal benefits, such as energy savings and reductions in air pollution, in short- to long-term framework.

The third conclusion is that the three projects assessed all appear to have yielded high levels of benefits. From the qualitative assessment, all met their technical goals, increased knowledge, and led to increased collaboration. It is not likely that these projects would have been undertaken without federal support or at least undertaken as soon as they were. The only open question pertains to commercialization. With respect to the National Research Council indicators, there was a mixed rate of publication but each project improved U.S. competitiveness in its respective area. The benefit-cost analysis yielded impressive benefit-to-cost ratios, ranging from 168:1 to 699:1, when environmental benefits are taken into consideration.

Future efforts should consider improving the application of the methods in the following ways. With respect to the qualitative assessment, key participants should be informed that they will be interviewed after the project is completed. The National Research Council indicators should be expanded to include additional categories of intellectual achievement, such as patents and copyrights. With respect to the benefit-cost analysis, uncertainty needs to be more explicitly treated. More sophisticated methods, such as option pricing analysis, should be considered. Lastly, to improve the assessment of long-term benefits, publications and market penetration rates should be periodically revisited, and case studies should be undertaken to identify any valuable spin-off technologies. 



\section{ACKNOWLEDGMENTS}

We wish to acknowledge Jonathan Overly and Rajive Dhingra of the Center for Clean Products and Clean Technology, University of Tennessee, Knoxville for their assistance with this project. For their constructive critiques of earlier versions of this report, we wish to thank the following people: Jack Barkenbus, Dave Bjornstad, Marilyn Brown, Michael Gallaher, Stan Hadley, Marc Ross, and William White. Their comments were particularly helpful in improving, although by no means perfecting, the benefit-cost analysis. We also wish to thank Tina Cordy, Cathy Hagman, and Sumer Yates for their assistance with the interviews; Debbie Bower, Constance Griffith, Nancy Jett, and Sheila Moore for their editorial assistance. 



\section{REFERENCES}

Alston, J. M., G. W. Norton, and P. G. Pardey. 1995. Science Under Scarcity: Principles and Practice for Agricultural Research Evaluation and Priority Setting. Cornell University Press, Ithaca, NY.

Alston, J. M. and E. D. Beach. 1996. "Market Distortions and the Benefits from Research into New Uses for Agricultural Commodities: Ethanol from Corn." Resource and Energy Economics. 18, pp. 1-29.

American Metal Market (AMM). 1999. Dec. 6, p. 9.

Ammons, D. N. 1995. Accountability for Performance: Measurement and Monitoring in Local Government. International City/County Management Association, Washington, DC.

Angelis, D. I. 2000. “Capturing the Option Value of R\&D," Research Technology Management, pp. 31-34, July-August.

Automotive Composites Alliance (ACA). 2000. 2000 Model Year Passenger Car and Truck Thermoset Composite Components. Troy, MI.

Babbie, E. 1998. The Practice of Social Research. $8^{\text {th }}$ edition, Wadsworth Publishing Company, Belmont, CA.

Bozeman, B., and J. Melkers, Eds. 1993. Evaluating R\&D Impacts: Methods and Practice. Kluwer Academic Publishers, Boston, MA.

Bozeman, B. 1993. "Peer Review and Evaluation of R\&D Impacts." In Evaluating $R \& D$ Impacts: Methods and Practice. Eds. B. Bozeman and J. Melkers. Kluwer Academic Publishers, Boston, MA.

Brown, E. A. 1996. Applying the Principles of the Government Performance and Results Act to the Research and Development Function: A Case Study submitted to the Office of Management and Budget by the Army Research Laboratory. The Congressional Institute, Washington, DC. Accessed 6/12/01. http://www.conginst.org/resultsact/reports/ReportResearchDevelopment/casearl.html.

Brown, K. M. 1998. Downsizing Science: Will the United States Pay a Price? The AEI Press, Washington, DC.

Brown, M. A. and C. R. Wilson. 1993. "R\&D Spinoffs: Serendipity vs. a Managed Process." Technology Transfer, 18, Nos. 3-4, pp. 5-15, Summer-Fall.

Brown, M. A., T. R. Curlee, and S. R. Elliott 1994. "Evaluating technology innovation programs: the use of comparison groups to identify impacts." Research Policy, 24, pp. 669684.

Brunnermeier, S. B. and S. A. Martin. 1999. Interoperability Cost Analysis of the U.S. Automotive Supply Chain. NIST 99-1. Report prepared by Research Triangle Institute, Research Triangle Park, North Carolina, for National Institute of Standards and Technology.

Chapman, R. C. and S. K. Fuller. 1996. Benefits and Costs of Research: Two Case Studies in Building Technology. NISTIR 5840. U.S. Department of Commerce, Technology Administration, National Institute of Standards and Technology, Gaithersburg, MD. July.

Chapman, R. C. 1999. Benefits and Costs of Research: A Case Study of Cybernetic Building Systems. NISTIR 6303. U.S. Department of Commerce, Technology Administration, 
National Institute of Standards and Technology, Gaithersburg, MD. March.

Chapman, R. C. 2000. Benefits and Costs of Research: A Case Study of Construction Systems Integration and Automation Technologies in Industrial Facilities. NISTIR 6501. U.S.

Department of Commerce, Technology Administration, National Institute of Standards and Technology, Gaithersburg, MD. June.

Chavka, N. G., J. S. Dahl, and E. D. Kleven. 2001. F3P Fiber Preforming for the Aston Martin Vanquish. Presented at the Annual SAMPE Europe International Conference, CNIT Conference Center, Paris, France, March.

Composites Technology. 2000. "Truck Makers Choose Different Routes for Cargo Boxes." Mar./Apr., p. 19-22.

Composites Technology. 2001. "Automotive Market Will Drive Increased Composites Use, Say Two Sources.” Mar./Apr., p. 10.

Denton et. al. 2000. Development of a Cost-Effective SRIM Manufacturing Process for a Composite Truck Box." Proceedings of the SAMPE-ACCE-DOE-SPE Midwest Advanced Materials and Processing Conferences, Dearborn, Michigan, Sept. 12-14.

Dietz, F. 1997. "Government Partnerships Benefit Small Businesses." Mechanical Engineering. 199, No. 11, pp. 36-37, November.

Ernst, H. 1998. "Industrial Research as a Source of Important Patents." Research Policy. 29, pp. 1-15.

Fischer, F. 1995. Evaluating Public Policy. Nelson-Hall Publishers, Chicago, IL.

Fitzsimmons, C. B. 2001. "Knowledge Spillovers from Joint Government-Industry Supported Research: A Case-Study from the Automotive Industry." Ph.D. dissertation, George Mason University, Fairfax, Virginia, Spring.

Folz, D. H., 1996. Survey Research for Public Administration. Sage Publications, Thousand Oaks, CA.

Gallaher, M. P. and S. A. Martin. 1999. Benefit Analysis of IGBT Power Device Simulation Modeling. NIST Report No. 99-3, RTI Project No. 7007-02. Report prepared by Research Triangle Institute, Research Triangle Park, North Carolina, for National Institute of Standards and Technology.

Geisler, E. 1995. "An Integrated Cost-performance Model of Research and Development Evaluation." Omega, International Journal of Management Science. 23, No. 3, pp. 281-294.

Gelijns, A., N. Rosenberg, and A. J. Moskowitz. 1998. "Capturing the Unexpected Benefits of Medical Research.” New England Journal of Medicine. 399, No. 10, September 3, pp. 693698.

Gibson, D. V. and E. M. Rogers. 1994. R\&D Collaboration on Trial: The Microelectronics and Computer Technology Corporation. Harvard Business School Press, Boston, MA.

Griliches, Z. 1998. R\&D and Productivity: The Econometric Evidence. University of Chicago Press, Chicago, IL.

Hamilton, S. F. and D. L. Sunding. 1998. "Returns to Public Investments in Agriculture with Imperfect Downstream Competition." American Journal of Agricultural Economics. 80, pp. 830-838, November.

Hendrick, R. 1994. “An Information Infrastructure for Innovative Management of Government." 
Public Administration Review. 54, No. 6, pp. 543-549, November/December.

Hyde, W. F., D. H. Newman, and B. J. Seldon. 1992. The Economic Benefits of Forestry Research. Iowa State University Press, Ames, IA.

Kingsley, G. 1993. "The Use of Case Studies in R\&D Impact Evaluations.” In Evaluating R\&D Impacts: Methods and Practice. Eds. B. Bozeman and J. Melkers. Kluwer Academic Publishers, Boston, MA.

Langbein, L. I. 1980. Discovering Whether Programs Work: A Guide to Statistical Methods for Program Evaluation. Scott, Foresman and Company, Glenview, IL.

Link, A. N. 1993. "Methods for Evaluating the Return on R\&D Investments." In Evaluating R\&D Impacts: Methods and Practice. Eds. B. Bozeman and J. Melkers. Kluwer Academic Publishers, Boston, MA.

Link, A. N. 1995. "Evaluating Program Performance: The Case of Federally-funded Collaborative Research." International Journal Technology Management. 10, Nos. 7/8, pp. 847-852.

Link, A. N., D. J., Teece, and W. F. Finan. 1996. "Estimating the Benefits from Collaboration: The Case of SEMATECH.” Review of Industrial Organization. 11, pp. 737-751.

Link, A. N. and J. T. Scott. 1998. Public Accountability: Evaluating Technology-Based Institutions. Kluwer Academic Publishers, Boston, MA.

MacRae, Duncan, Jr., and Dale Whittington, Expert Advice for Policy Choice: Analysis and Discourse (Washington, DC: Georgetown University Press), 1997.

Mansfield, E. 1995. Innovation, Technology and the Economy: Selected Essays of Edwin Mansfield. 2 vol., Economists of the Twentieth Century Series, Elgar Publishers, Aldershot, United Kingdom.

Martin, S. A., M. P. Gallager, and A. C. O’Connor. 2000. Economic Impact of Standard Reference Materials for Sulfur in Fossil Fuels. NIST Report No. 00-1, RTI Project Number 7007-006. Report prepared by Research Triangle Institute, Research Triangle Park, North Carolina, for National Institute of Standards and Technology, February.

Marx, M. L., J. T. Scott, and S. M. Fry. 2000. Economic Impact Assessment: NIST-EEEL Laser and Fiberoptic Power and Energy Calibration Services. NIST 00-3. Report prepared by TASC, Inc., Arlington, Virginia, for National Institute of Standards and Technology, August.

Melkers, J. 1993. "Bibliometrics as a Tool for Analysis of R\&D Impacts.” In Evaluating R\&D Impacts: Methods and Practice Eds. B. Bozeman and J. Melkers. Kluwer Academic Publishers, Boston, MA.

Mowery, D. C. and R. R. Nelson. 1999. Sources of Industrial Leadership: Studies of Seven Industries. Cambridge University Press, Cambridge, UK.

National Academy of Sciences (NAS). 1999. Evaluating Federal Research Programs: Research and the Government Performance and Results Act. National Academy Press, Committee on Science, Engineering, and Public Policy, Washington, DC.

National Research Council (NRC). 1994. Organizational Linkages: Understanding the Productivity Paradox. National Academy Press, Washington, DC. 
Nelson, R. R., J. Peck and E. D. Kalachek. 1967. Technology, Economic Growth, and Public Policy. The Brookings Institution, Washington, DC.

Nelson, R. R. and S. G. Winter. 1982. An Evolutionary Theory of Economic Change. Harvard University Press, Cambridge, MA.

Papadakis, M. and A. N. Link. 1997. "Measuring the Unmeasurable: Cost-Benefit Analysis for New Business Start-ups and Scientific Research Transfers." Evaluation and Program Planning. 20, No. 1, pp. 91-102.

Posavac, E. J. and R. G. Carey. 1985. Program Evaluation: Methods and Cases. $2^{\text {nd }}$ edition, Prentice-Hall, Inc., Englewood Cliffs, NJ.

Radin, B. A. 1998. "The Government Performance and Results Act (GPRA): Hydra-Headed Monster or Flexible Management Tool?" Public Administration Review. 58, No. 4, pp. $307-$ 315, July/August.

Reinhart, T. 1999. "The Potential of Oriented, Discontinuous Carbon Fiber Preforms for Low Cost High Performance Aerospace Structures." Presented at the SAMPE-ACEE-DOE Advanced Composite Conference, Planes, Trains, Automobiles, and Bridges Too. Detroit, Sept.

Reynolds Metals Company. 1999. "Low Cost Aluminum Sheet for Automotive Applications; Final Report.” CRADA No. LA95C10245-A001. Corporate Technology Center, Corporate Research and Development, November.

Riggert, Jeff; Andrew Oh, Nicholas P. Hall, John H. Reed. 1999. "An Evaluation of the Energy and Non-energy Impacts of Vermont's Weatherization Assistance Program. TecMRKT Works, Oregon, WI, November.

Rossi, P. H. and H. E. Freeman. 1985. Evaluation: A Systematic Approach. $3^{\text {rd }}$ edition, Sage Publications, Inc., Beverly Hills, CA.

Rouse, W. B., K. R. Boff, and B. G. Sutley Thomas. 1997. "Assessing Cost/Benefits of Research and Development Investments." IEEE Transactions on Systems, Man, and Cybernetics. 27, No. 4, pp. 389-401, July.

Scherer, F. M. 1965. "Government Research and Development Programs." In Measuring Benefits of Government Investments. Ed. Robert Dorfman, The Brookings Institution, Washington, DC.

Schultz, R. A. 1999. Aluminum for Light Vehicles: An Objective Look at the Next Ten to Twenty Years. Presented at the Metal Bulletin $14^{\text {th }}$ International Aluminum Conference, Montreal, Canada, Sept. 15.

Schultz, R. A. 2001a. A Realistic Assessment of Future Worldwide Automotive Aluminum Use. Presented at Commodity Metals Management Aluminum Trends Seminar, Naples, France, Apr. 3.

Schultz, R. A. 2001b. Aluminum for Light Vehicle Bodies in North America: An Objective Look at the Next Ten Years. Presented at the University of Michigan Management Briefing Seminars World Class Manufacturing Session, Traverse City, Michigan, August 8.

Torpey, P. J. 1994. “Collaborative R\&D Helps Companies Stay Competitive.” Mechanical Engineering. 116, No. 10, pp. 85-86, October.

U. S. Congress 1993. Government Performance and Results Act of 1993. Pub. L 103-62. 
U.S. General Accounting Office (GAO). 1997. Measuring Performance: Strengths and Limitations of Research Indicators. GAO/RCED-97-91. GAO, Washington, DC. March.

Wards Communications (WC). 2000. Ward's Motor Vehicle Facts \& Figures, Southfield, Michigan.

Yin, R. K. 1984. Case Study Research : Design and Methods. Sage Publications, Beverly Hills, California.

Yuracko, K., B. Tonn, and M. Morris. 1999. Assessment of Cost Savings of DOE's Return-onInvestment Program. ORNL/TM-1999/155, Oak Ridge National Laboratory, Oak Ridge, Tennessee. 